\title{
Analisis Penilaian Kinerja Terhadap Rasionalitas Dosen pada 114 Perguruan Tinggi Swasta (PTS) Wilayah Kopertis XIII Provinsi Aceh dengan Metode Technique for Order Preference by Similarity to Ideal Solution (TOPSIS)
}

\author{
Munawir \\ AMIK Indonesia
}

\section{article info}

\section{Article history:}

Received 11 Desember 2017

Received in revised form

23 January 2018

Accepted 28 Februari 2018

Available online 20 Maret

2018

\section{Keywords:}

Analysis, Rationality

Lecturer, Technique for

Order Preference by

Similarity to Ideal Solution

(TOPSIS) a b s tract

This research aims to make a sort 104 University in Region XIII Kopertis Aceh Province with the method Technique for Order Preference by Similarity to Ideal Solution (TOPSIS) against the ratio of lecturers and students. TOPSIS is one method that can be used to solve the problem of Fuzzy MADM. This research takes into account all the criteria that support decision making in order to help speed up and facilitate the decision-making process and do a minimal quantity of perangkingan especially the lecturer at a college. Based on research results, calculation of TOPSIS begins with forming a decision matrix is normalized, then continued with a decision matrix weighting normalization. The step is done to determine the ideal solution matrix of positive and negative solution is ideal. The last stages of the method is to calculate the value of the preference of each alternative ( $\mathrm{Vi}$ ) in order to get the final results, the most high value Vi shows the best alternative. Based on the end result then sorted 25 Colleges (PTS) is Locality Kopertis XIII Aceh at its best.

\section{a b s tra k}

Penelitian ini bertujuan untuk membuat sebuah perangkingan 104 perguruan tinggi swasta di Wilayah Kopertis XIII Provinsi Aceh dengan Metode Technique for Order Preference by Similarity to Ideal Solution (TOPSIS) terhadap rasio dosen dan mahasiswa. TOPSIS merupakan salah satu metode yang dapat digunakan untuk menyelesaikan masalah Fuzzy MADM. Penelitian ini memperhitungkan segala kriteria yang mendukung pengambilan keputusan guna membantu mempercepat dan mempermudah proses pengambilan keputusan dan melakukan perangkingan khususnya kuantitas minimal dosen pada sebuah Perguruan Tinggi. Berdasarkan hasil penelitian, perhitungan TOPSIS diawali dengan membentuk matriks keputusan yang kemudian dinormalisasi, dilanjutkan dengan pembobotan matriks keputusan ternormalisasi. Langkah tersebut dilakukan untuk menentukan matriks solusi ideal positif dan solusi ideal negatif. Tahapan terakhir dari metode ini yaitu menghitung nilai preferensi dari masingmasing alternatif (Vi) guna mendapatkan hasil akhir, nilai Vi yang paling tinggi menunjukkan alternatif terbaik yang terpilih. Berdasarkan dengan hasil akhir maka diurutkan 25 Perguruan Tinggi Swasta (PTS) Wilayah Kopertis XIII Aceh yang terbaik.

*Corresponding author. Email: munawir@amikindonesia.ac.id

(C) E-ISSN: 2580-1643.

Copyright@2018. Published by Lembaga Informasi dan Riset (KITA INFO dan RISET), Lembaga KITA

(http://creativecommons.org/licenses/by/4.0/). 


\section{Latar Belakang}

Instansi atau organisasi adalah suatu kumpulan orang yang saling bekerja sama untuk mencapai suatu tujuan (Sarboini dan Jen Surya, 2017:87). Peningkatan kualitas pelayanan merupakan salah satu isu penting dalam lembaga Pendidikan (Irma., dkk, 2013:118). Sumber daya manusia menjadi aset penting yang wajib dimiliki oleh suatu Perusahaan atau organisasi untuk dibina sebaik mungkin, disisi lain juga perlu penanganan yang serius terhadap rendahnya kualitas Sumber Daya Manusia (Syamsul Rizal, 2017:37). Kompleksitas horizontal maupun kompleksitas vertikal dalam sebuah organisasi dapat menyebabkan terjadinya perbedaan di antara beberapa tugas dan fungsi dalam suatu organisasi terkait dengan struktur organisasi yang bersangkutan (Ihsanuddin, 2014:356).

Investasi di bidang Sumber Daya Manusia (SDM) merupakan investasi yang sangat penting, sekaligus memerlukan perhatian khusus dalam penanganannya (Joni dan Ariana, 2016:24). Sumber daya manusia merupakan salah satu faktor yang menentukan efektifitas dan produktifitas suatu organisasi, Keberhasilan semua jenis organisasi pada dasarnya bergantung pada keahlian dan kemampuan komunitas para karyawan yang membentuknya (Munawir dan Ardiansyah, 2017:8). Upaya pemberdayaan tenaga kerja tidak hanya dilakukan dengan cara menempatkan seseorang pada bidang pekerjaan yang sesuai dengan kemampuan dan keterampilan kerja yang dimiliki (Ahmad, 2016:43). Dalam konteks globalisasi, daya saing merupakan kunci utama untuk mampu bertahan baik dari sisi kualitas maupun produktivitas (Nasir dan Muhammad, 2017:432).

Berkaitan dengan hal peningkatan Sumber Daya Manusia dalam suatu Perguruan Tinggi menjadi hal yang patut dinilai dalam peningkatan kualitas dalam suatu Lembaga, kuantitas juga menjadi pertimbangan sebagai tolak ukur dalam perbandingan rasionalitas. Dalam manajemen pengelolaan Perguruan Tinggi juga diatur Sumber Daya Manusia yaitu dosen pada suatu Program Studi yang mewajibkan Setiap prodi minimal memiliki 6 dosen tetap, Pemetaan dilakukan terhadap Data setiap prodi dalam PDPT. Untuk setiap prodi rasio maksimum jumlah dosen tetap terhadap jumlah mahasiswa adalah $1: 20$ untuk prodi eksakta dan 1 : 30 untuk prodi non eksakta.

Hal tersebut juga diatur dalam peraturan yaitu; Undang-Undang Nomor 20 Tahun 2003 tentang Sistem Pendidikan Nasional menyebutkan bahwa pendidik diantaranya dapat berupa dosen, instruktur, dan tutor. Undang-Undang Nomor 14 Tahun 2005 tentang Guru dan Dosen menegaskan bahwa status dosen terdiri atas dosen tetap dan dosen tidak tetap, dan penjelasan Nomor registrasi dimaksud telah ditetapkan dalam Peraturan Menteri Riset, Tekologi dan Pendidikan Tinggi Nomor 26 Tahun 2015 tentang Registrasi Pendidik pada Perguruan Tinggi. Sejak tahun 2011, NIDN hanya diberikan kepada dosen tetap, sedangkan dosen tidak tetap diberikan Nomer Urut Pengajar Nasional (NUPN). Perubahan kebijakan ini salah satunya dalam rangka menindaklanjuti peraturan tentang adanya dosen tetap dan dosen tidak tetap. UndangUndang Nomor 12 Tahun 2012 tentang Pendidikan Tinggi, Pasal 56 mengamanatkan bahwa setiap perguruan tinggi harus melaporkan data dan informasi dengan baik dan benar melalui Pangkalan Data Pendidikan Tinggi (PDDIKTI).

Berdasarkan data pada PDDIKTI tahun 2015, banyak program studi yang tidak memenuhi persyaratan rasio dosen tetap terhadap mahasiswa. Hal ini disebabkan berbagai hal, salah satu diantaranya adalah sulitnya mendapatkan dosen yang bersedia secara penuh waktu untuk melaksanakan Tridharma Perguruan Tinggi. Selain itu, banyak para profesional dari instansi pemerintah maupun swasta baik yang masih aktif maupun sudah purna tugas, dan secara kualifikasi memenuhi persyaratan sebagai dosen di perguruan tinggi belum dimanfaatkan atau belum diakui legalitasnya sebagai dosen. Untuk mengatasi hal tersebut, diterbitkan Peraturan Menteri Riset, Teknologi, dan Pendidikan Tinggi Nomor 26 Tahun 2015 tentang Registrasi Pendidik pada Perguruan Tinggi. Namun dalam implementasinya terdapat perkembangan dalam pelaksanaan registrasi pendidik, sehingga Peraturan Menteri Riset, Teknologi, dan Pendidikan Tinggi Nomor 26 Tahun 2015 tentang 
Registrasi Pendidik pada Perguruan Tinggi perlu diubah. Satu program studi di sebuah perguruan tinggi minimum harus memiliki 6 (enam) orang dosen yang berlatar belakang keilmuan relevan dengan program studi yang diasuh, kecuali program studi yang diatur secara khusus. Dosen dan mahasiswa di sebuah program studi harus memiliki rasio yang ideal. Rasio dosen terhadap mahasiswa pada program studi, yaitu:

a. 1 (satu) : 45 (empat puluh lima) untuk rumpun ilmu agama, rumpun ilmu humaniora, rumpun ilmu sosial, dan/atau rumpun ilmu terapan (bisnis, pendidikan, keluarga dan konsumen, olahraga, jurnalistik, media massa dan komunikasi, hukum, perpustakaan dan permuseuman, militer, administrasi publik, dan pekerja sosial); dan

b. 1 (satu) : 30 (tiga puluh) untuk rumpun ilmu alam, rumpun ilmu formal, dan/atau rumpun ilmu terapan (pertanian, arsitektur dan perencanaan, teknik, kehutanan dan lingkungan, kesehatan, dan transportasi).

Setiap dosen di sebuah program studi yang memenuhi persyaratan berhak memperoleh nomor registrasi pendidik baik NIDN, NIDK, maupun NUP. Komposisi jumlah dosen yang memiliki NIDN harus lebih banyak dari pada jumlah dosen yang memiliki NIDK dan paling sedikit memiliki NIDN 6 (enam) orang per program studi, kecuali untuk program studi dokter, dokter spesialis dapat 50\% (lima puluh persen) yang memiliki NIDN dan 50\% (lima puluh persen) yang memiliki NIDK. Dengan adanya peraturan dan ketentuan pengelolaan Program Studi di Perguruan Tinggi menjadi hal yang harus diperhatikan dengan serius untuk pencapaian minimal rasionalitas dosen dan mahasiswa, semakin banyak jumlah dosen tetap maka semakin baik suatu Perguruan Tinggi.

Pentingnya mengukur rasio dosen pada sebuah Perguruan Tinggi menjadi pertimbangan dasar dalam meningkatkan kualitas Lembaga, peningkatan akreditasi Program Studi itu sendiri. Metode Technique for Order Preference by Similarity to Ideal Solution (TOPSIS) menjadi solusi dalam menganalisis dan sebagai acuan pengambilan keputusan di Perguruan Tinggi. Selama ini banyak penelitian yang menghasilkan informasi kinerja dalam suatu lembaga Pendidikan dengan berbagai metode digunakan.

Boran, et al (2009:11363) Metode TOPSIS dikombinasikan dengan perangkat furqy intuitionistic dapat digunakan untuk informasi yang tepat dalam pengambilan keputusan suatu instansi atau kelompok. Dalam kehidupan sehari-hari pengambilan keputusan sering menggunakan intuisi, walaupun metode ini banyak sekali kekurangan sehingga dikembangkan sistematika baru yang disebut dengan analisis keputusan, yaitu kecerdasan, persepsi, dan falsafah. Setelah menggunakan kecerdasan, persepsi, dan falsafah untuk membuat model, menentukan nilai kemungkinan, menetapkan nilai pada hasil yang diharapkan dan menjajaki preferensi terhadap waktu dan preferensi terhadap resiko, maka untuk sampai pada suatu keputusan diperlukan logika (Pohan, 2017:84).

TOPSIS memiliki konsep dimana alternatif yang terpilih merupakan alternatif terbaik yang memiliki jarak terpendek dari solusi ideal positif dan jarak terjauh dari solusi ideal negatif. Semakin banyaknya faktor yang harus dipertimbangkan dalam proses pengambilan keputusan, maka semakin relatif sulit juga untuk mengambil keputusan terhadap suatu permasalahan (Rifai dan Arsalan, 2017:308). Fuzzy TOPSIS terbukti mampu menghasilkan keputusan yang cukup efektif, efisien, dan objektif (Chamid dan Murti, 2017:116).

Secara umum, prosedur metode TOPSIS mengikuti langkah-langkah :

a. Menentukan matrik keputusan yang ternormalisasi;

b. Menghitung matrik keputusan yang ternormalisasi terbobot;

c. Menghitung matrik solusi ideal positif dan matrik solusi ideal negatif;

d. Menghitung jarak antara nilai setiap alternative dengan matrik solusi ideal positif dan matrik solusi ideal negatif;

e. Menghitung nilai preferensi untuk setiap alternative

(Prasetyanti dan Listyaningrum, 2017:10).

Konsep dasar dari metode TOPSIS yaitu bahwa 
alternatif terbaik yang nantinya terpilih tidak hanya memiliki jarak terpendek dari solusi ideal positif akan tetapi juga memiliki jarak terpanjang dari solusi ideal negatif dari sudut pandang geometris dengan menggunakan jarak Euclidean (Faza dan Supriyanto, 2016:3). Algoritma dari metode TOPSIS sebagai berikut:

a. Dimulai dengan membangun sebuah matriks keputusan yaitu melakukan evaluasi $\mathrm{m}$ alternatif dalam sebuah matriks keputusan $\mathrm{X}$ berdasarkan $\mathrm{n}$ kriteria, dapat dilihat pada persamaan berikut :

$$
\begin{aligned}
& \begin{array}{lllll}
x_{1} & x_{2} & x_{3} & \cdot & x_{n}
\end{array}
\end{aligned}
$$

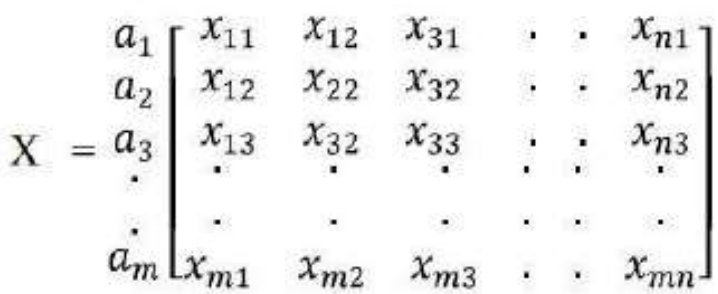

b. Membuat matriks keputusan yang ternormalisasi yaitu untuk mentransformasikan setiap elemen xij dapat digunakan dengan persamaan berikut :

$$
r_{i j}=\frac{x_{i j}}{\sqrt{\sum_{i=1}^{m} x_{i j}^{2}}}
$$

c. Membuat matriks keputusan yang ternormalisasi terbobot. Dengan bobot $w j=($ $\left.w 1, w 2, w^{3}, \ldots, w n\right)$, dimana $w j$ adalah bobot dari kriteria ke-j dan $\Sigma$, maka normalisasi bobot matriks $V$ adalah :

$$
v i j=w j{ }^{*} r i j
$$

d. Menentukan matriks solusi ideal positif dan solusi ideal negatif. Solusi ideal positif dinotasikan $A+$, sedangkan solusi ideal negatif dinotasikan $A$-. Berikut ini adalah persamaan dari $A+$ dan $A-$ :

$A+=\left\{(\max v i j \mid \mathrm{j} € \mathrm{~J}),(\min v i j \mid \mathrm{j} € \mathrm{~J})^{\prime}, \mathrm{i}=\right.$ $1,2,3, \ldots, \mathrm{m}\}$

$=\left\{v_{1}^{+}, v_{2}^{+}, v_{3}^{+}, \ldots, v_{n}^{+}\right\}$

A- $=\left\{(\min v i j \mid \mathrm{j} € \mathrm{~J}),\left(\max v i j \mid \mathrm{j} € \mathrm{~J}{ }^{\prime}\right), \mathrm{i}=\right.$ $1,2,3, \ldots, \mathrm{m}\}$

$$
=\left\{v_{1}^{-}, v_{2}^{-}, v_{3}^{-}, \ldots, v_{n}^{-}\right\}
$$

e. Menghitung jarak solusi ideal positif $(D+)$ dan solusi ideal negatif (D-).

$D+$ adalah jarak alternatif dari solusi ideal positif, berikut adalah persamaan dari $D+$ :

$$
D_{i}^{+}=\sqrt{\sum_{j=1}^{n}\left(v_{j}^{+}-v_{i j}\right)^{2}}
$$

$D$ - adalah jarak alternatif dari solusi ideal negatif, berikut adalah persamaan dari $D$ - :

$$
D_{i}^{-}=\sqrt{\sum_{j=1}^{n}\left(v_{j}^{-}-v_{i j}\right)^{2}}
$$

f. Menghitung nilai preferensi untuk setiap alternatif. Nilai preferensi merupakan nilai kedekatan relatif dari setiap alternatif terhadap solusi ideal positif, untuk mencari nilai tersebut dapat menggunakan persamaan berikut ini :

$$
V_{i}=\frac{D_{i}^{-}}{D_{i}^{-}+D_{i}^{+}}
$$

g. Meranking alternatif. Langkah terakhir setelah semua perhitungan selesai, yaitu mengurutkan alternatif dari nilai $V i$ terbesar ke nilai terkecil. alternatif dengan nilai $V i$ terbesar merupakan solusi terbaik.

Dalam penelitian ini, PTS yang dimaksudkan adalah 114 (seratus empat belas) PTS di Wilayah Kopertis Wilayah XIII Provinsi Aceh meliputi:

Tabel 1. Daftar PTS Wilavah Kopertis XIII Aceh

\begin{aligned} No & \multicolumn{1}{c}{ Perguruan Tinggi } \\ \hline 1 & Universitas Jabal Ghafur \\ 2 & Universitas Iskandar Muda \\ 3 & Universitas Abulyatama \\ 4 & Universitas Muhammadiyah Aceh \\ 5 & Universitas Serambi Mekkah \\ 6 & Universitas Al Muslim \\ 7 & Universitas Gajah Putih \\ 8 & Universitas Gunung Leuser Aceh \\ 9 & Universitas Ubudiyah Indonesia \\ 10 & Universitas Sains Cut Nyak Dhien \end{aligned}




\begin{tabular}{|c|c|}
\hline No & Perguruan Tinggi \\
\hline 11 & $\begin{array}{l}\text { Sekolah Tinggi Ilmu Ekonomi Indonesia Banda } \\
\text { Aceh }\end{array}$ \\
\hline 12 & Sekolah Tinggi Ilmu Manajemen \\
\hline 13 & Sekolah Tinggi Ilmu Ekonomi Sabang \\
\hline 14 & STMIK Abulyatama \\
\hline 15 & Sekolah Tinggi Ilmu Kehutanan Pante Kulu \\
\hline 16 & Sekolah Tinggi Ilmu Administrasi Iskandar Thani \\
\hline 17 & Sekolah Tinggi Teknik Iskandar Thani \\
\hline 18 & Sekolah Tinggi Ilmu Manajemen Pase \\
\hline 19 & Sekolah Tinggi Ilmu Ekonomi YPHB \\
\hline 20 & Sekolah Tinggi Teknik Bina Cendikia \\
\hline 21 & $\begin{array}{l}\text { Sekolah Tinggi Ilmu Hukum Muhammadiyah } \\
\text { Takengon }\end{array}$ \\
\hline 22 & STMIK Bina Bangsa \\
\hline 23 & $\begin{array}{l}\text { Sekolah Tinggi Ilmu Manajemen Indonesia } \\
\text { Meulaboh }\end{array}$ \\
\hline 24 & Sekolah Tinggi Ilmu Psikologi Harapan Bangsa \\
\hline 25 & Sekolah Tinggi Ilmu Administrasi Nasional \\
\hline 26 & STKIP Al-Washliyah \\
\hline 27 & STKIP An-nur Nangro Aceh \\
\hline 28 & STKIP Bina Bangsa Getsempena \\
\hline 29 & Sekolah Tinggi Ilmu Pertanian Yashafa \\
\hline 30 & STKIP Muhammadiyah Aceh Tengah \\
\hline 31 & Sekolah Tinggi Ilmu Kesehatan Harapan Bangsa \\
\hline 32 & STIKES Payung Negeri Aceh Darussalam \\
\hline 33 & STISIP Al Washliyah Banda Aceh \\
\hline 34 & STIE Bumi Persada Lhokseumawe \\
\hline 35 & STIKES Cut Nyak Dhien Langsa \\
\hline 36 & Sekolah Tinggi Ilmu Ekonomi Lhokseumawe \\
\hline 37 & Sekolah Tinggi Ilmu Kesehatan Langsa \\
\hline 38 & STIKES Darussalam Lhokseumawe \\
\hline 39 & STIKES Muhammadiyah Lhokseumawe \\
\hline 40 & STIKES Medika Seramoe Barat \\
\hline 41 & STIKES Darussalam Lhokseumawe \\
\hline 42 & STIKES Muhammadiyah Lhokseumawe \\
\hline 43 & STIKES Medika Seramoe Barat \\
\hline 44 & STIKES Medika Nurul Islam \\
\hline 45 & Sekolah Tinggi Ilmu Administrasi Pelita Nusantara \\
\hline 46 & STIKES Bumi Persada Lhokseumawe \\
\hline 47 & STIKES Getsempena Lhoksukon \\
\hline 48 & STIKES Bina Nusantara \\
\hline 49 & $\begin{array}{l}\text { Sekolah Tinggi Ilmu Ekonomi Kebangsaan } \\
\text { Bireuen }\end{array}$ \\
\hline
\end{tabular}

STKIP Muhammadiyah Aceh Barat Daya

STIKES Nurul Hasanah Kutacane

STKIP Bina Bangsa Meulaboh

STKIP Usman Safri Kutacane

STKIP Bumi Persada Lhokseumawe

STIKES Medika Teuku Umar

STIKES Bustanul Ulum Langsa

STMIK Indonesia Banda Aceh

STKIP Citra Bangsa Aceh Utara

Sekolah Tinggi Manajemen Informatika dan Komputer Harapan Ibu

AMIK Indonesia

Akademi Pariwisata Muhammadiyah Banda Aceh

Akademi Keuangan Perbankan Nusantara

AMIK Jabal Ghafur

Akademi Maritim Nusantara Malahayati

Akademi Maritim Aceh Darussalam

Akademi Perikanan Dan Ilmu Kelautan

Akademi Kebidanan Darussalam

Akademi Keperawatan Yappkes Aceh Singkil

Akademi Keperawatan Teungku Fakinah Banda Aceh

Akademi Kebidanan Public Health Medical Nursing

Akademi Kebidanan Saleha

Akademi Kebidanan Harapan Ibu Langsa

Akademi Kebidanan Nurul Hasanah

Akademi Kebidanan Yayasan Pendidikan Mona

Akademi Kebidanan Medica Putro Bungsu

Akademi Kebidanan Nadhirah

Akademik Teknik Otomotif Banda Aceh

Akademi Kebidanan Medica Bakti Persada

Akademi Kebidanan Munawarrah Bireuen

Akademi Kebidanan Yayasan Pendidikan Mona

Akademi Kebidanan Medica Putro Bungsu

Akademi Kebidanan Nadhirah

Akademik Teknik Otomotif Banda Aceh

Akademi Kebidanan Medica Bakti Persada

Akademi Kebidanan Munawarrah Bireuen

Akademi Fisioterapi Harapan Bangsa Banda Aceh Akademi Analis Farmasi Dan Makanan Banda Aceh

Akademi Kebidanan Gayo Lues

Akademi Kebidanan Adhira Mustika Gayo

Akademi Kebidanan Darul Husada 


\begin{tabular}{|c|c|}
\hline No & Perguruan Tinggi \\
\hline 91 & Akademi Kebidanan Bunga Bangsa Idi \\
\hline 92 & Akademi Kebidanan Medica Alas Leuser \\
\hline 93 & Akademi Keperawatan Ibnu Sina Kota Sabang \\
\hline 94 & Akademi Kebidanan Pidie Jaya \\
\hline 95 & Akademi Farmasi YPPM Mandiri \\
\hline 96 & Akademi Kebidanan Medika Sri Tamiang \\
\hline 97 & Akademi Kebidanan Muhammadiyah Banda Aceh \\
\hline 98 & Akademi Keperawatan Abulyatama \\
\hline 100 & $\begin{array}{l}\text { Akademi Keperawatan Kesdam Iskandar Muda } \\
\text { Lhokseumawe } \\
\text { Akademi Keperawatan Kesdam Iskandar Muda } \\
\text { Banda Aceh }\end{array}$ \\
\hline 101 & Akademi Kesehatan Lingkungan Jabal Ghafur \\
\hline 102 & Akademi Keperawatan Jabal Ghafur \\
\hline 103 & Akademi kebidanan Meuligoe Nur Amin \\
\hline 104 & Akademi Perekam dan Info Kes Sihat Beurata \\
\hline 105 & Akademi Teknik Elektromedik Kupula Aceh \\
\hline 106 & Akademi Kebidanan Medika Anugerah Tasya \\
\hline 107 & $\begin{array}{l}\text { Akademi Teknik Radiodiagnostik Dan Radioterapi } \\
\text { (ATRO) Banda Aceh }\end{array}$ \\
\hline 108 & Akademi Fisioterapi Muhammadiyah Aceh \\
\hline 109 & Akademi Keperawatan Muhammadiyah Bireuen \\
\hline 110 & Akademi Manajemen Gunung Leuser \\
\hline 111 & Politeknik Aceh \\
\hline 112 & Politeknik Indonesia Venezuela \\
\hline 113 & Politeknik Aceh Selatan \\
\hline 114 & Politeknik Kutaraja \\
\hline
\end{tabular}

Sumber : Forlap DIKTI (Januari : 2018)

Pemilihan Perguruan Tinggi tersebut karena adanya perubahan tingkat pertumbuhan pada jumlah rasio SDM dan mahasiswa pada periode 2016/2017 dan 2017/2018. Dengan menggunakan metode TOPSIS diharapkan penelitian ini dapat menjadi kebaruan dalam topik penelitian perangkingan Perguruan Tinggi dengan menitikberatkan pada beberapa kriteria pembobotan dan menghasilkan sebuah alternatif terbaik.

\section{Metode Penelitian}

Penelitian ini dilakukan pada Perguruan Tinggi di Wilayah Kopertis XIII Provinsi Aceh, penulis menggunakan pendekatan deskriptif atau survey yaitu mengumpulkan data dari beberapa data primer oleh sumber data Kementerian Ristek Dikti yang digunakan sebagai acuan untuk rekomendasi perangkingan perguruan tinggi yang disebut sebagai alternatif. 114 Perguruan Tinggi dipiih dan yang paling tepat untuk salah satu elemen kunci dalam sebagai alternatif kriteria seperti ditunjukkan pada tabel 1. Setelah pra-evaluasi, enam sebagai alternatif untuk evaluasi lebih lanjut. Untuk mengevaluasi alternatif yang terdiri dari tiga kriteria dianggap penting sebagai berikut:

X1: Jumlah Dosen Tetap.

X2: Jumlah Mahasiswa.

X3: Rasio Dosen dan Mahasiswa.

Pada tahap ini akan dijelaskan cara kerja Furzy Multi Attribute Decision Making (FMADM) menggunakan metode TOPSIS. Adapun mekanisme pengujian dapat dilihat pada Gambar 1.

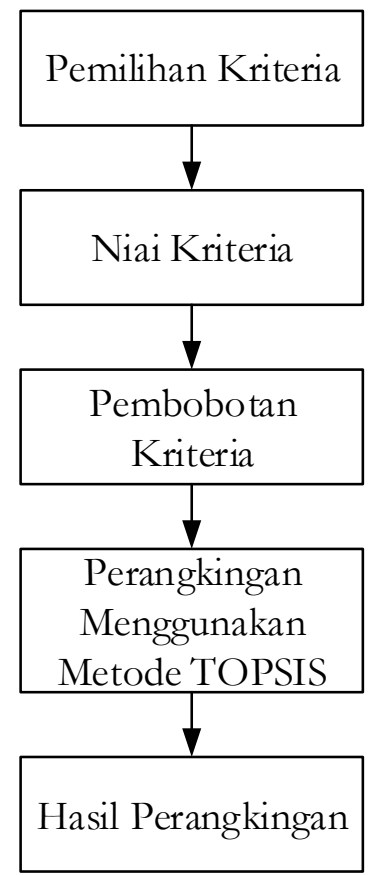

Gambar 1. Mekanisme pengujian

a. Pemilihan Kriteria, digunakan untuk menentukan/ acuan dalam menilai perguruan tinggi yang akan dipilih dalam hal ini Jumlah Dosen Tetap, Jumlah Mahasiswa, dan Rasio Dosen Tetap pada periode 2016/2017 dan 2017/2018.

b. Nilai Kriteria, yaitu memberikan nilai terhadap kriteria yang sudah ditentukan sebelumnya.

c. Pembobotan Kriteria, pemberian nilai kesesuaian terhadap kriteria rekomendasi perguruan tinggi.

d. Perangkingan Menggunakan Metode TOPSIS, melakukan perhitungan terhadap kriteria dengan bobot kesesuaian kriteria. 
e. Alternatif Terpilih, merupakan tahap perankingan, dimana akan terpilih perguruan tinggi yang direkomendasikan serta dirangking sebagai alternatif pilihan yang ditentukan dengan menggunakan FMADM menggunakan TOPSIS.

\section{Pembahasan}

Dimulai dengan membangun sebuah matriks keputusan. Berikut adalah tabel hasil konversi analisa rasionalitas dosen dan mahasiswa berdasarkan nilai tolok ukur yang sudah dipertimbangkan. Menghitung matriks keputusan ternormalisasi dengan menggunakan rumus :

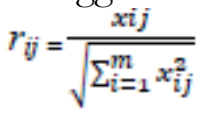

Maka dihasilkan matriks keputusan ternormalisasi sebagai berikut ini :

\section{Tabel 2. Matriks Keputusan Normalisasi}

\begin{tabular}{|c|c|c|c|c|c|c|}
\hline \multirow{4}{*}{ Alternatif } & \multicolumn{6}{|c|}{ Kriteria } \\
\hline & 3 & 2 & 5 & 3 & 2 & 5 \\
\hline & \multicolumn{3}{|c|}{$2016 / 2017$} & \multicolumn{3}{|c|}{$2017 / 2018$} \\
\hline & $\begin{array}{l}\text { Dosen } \\
\text { Tetap }\end{array}$ & $\begin{array}{l}\text { Maha } \\
\text { siswa }\end{array}$ & Rasio & $\begin{array}{l}\text { Dosen } \\
\text { Tetap }\end{array}$ & $\begin{array}{l}\text { Maha } \\
\text { siswa }\end{array}$ & Rasio \\
\hline $\begin{array}{l}\text { Universitas Jabal } \\
\text { Ghafur }\end{array}$ & 0.379 & 0.265 & 0.003 & 0.379 & 0.000 & 0.142 \\
\hline $\begin{array}{l}\text { Universitas } \\
\text { Iskandar Muda }\end{array}$ & 0.204 & 0.132 & 0.003 & 0.204 & 0.022 & 0.144 \\
\hline $\begin{array}{l}\text { Universitas } \\
\text { Abulyatama }\end{array}$ & 0.356 & 0.234 & 0.003 & 0.356 & 0.000 & 0.142 \\
\hline $\begin{array}{l}\text { Universitas } \\
\text { Muhammadiyah } \\
\text { Aceh }\end{array}$ & 0.260 & 0.448 & 0.224 & 0.260 & 0.827 & 0.004 \\
\hline $\begin{array}{l}\text { Universitas } \\
\text { Serambi Mekkah }\end{array}$ & 0.489 & 0.406 & 0.003 & 0.489 & 0.000 & 0.142 \\
\hline $\begin{array}{l}\text { Universitas } \\
\text { Muslim }\end{array}$ & 0.317 & 0.566 & 0.004 & 0.317 & 0.150 & 0.003 \\
\hline $\begin{array}{l}\text { Universitas } \\
\text { Gajah Puth }\end{array}$ & 0.116 & 0.081 & 0.003 & 0.116 & 0.000 & 0.142 \\
\hline $\begin{array}{l}\text { Universitas } \\
\text { Gunung Leuser } \\
\text { Aceh }\end{array}$ & 0.094 & 0.116 & 0.200 & 0.094 & 0.218 & 0.003 \\
\hline $\begin{array}{l}\text { Universitas } \\
\text { Ubudiyah } \\
\text { Indonesia }\end{array}$ & 0.146 & 0.083 & 0.003 & 0.146 & 0.004 & 0.002 \\
\hline $\begin{array}{l}\text { Universitas Sains } \\
\text { Cut Nyak Dhien }\end{array}$ & 0.099 & 0.026 & 0.003 & 0.099 & 0.077 & 0.003 \\
\hline $\begin{array}{l}\text { Sekolah Tinggi } \\
\text { Ilmu Ekonomi } \\
\text { Indonesia Banda } \\
\text { Aceh }\end{array}$ & 0.036 & 0.038 & 0.003 & 0.036 & 0.000 & 0.142 \\
\hline $\begin{array}{l}\text { Sekolah Tinggi } \\
\text { Ilmu } \\
\text { Manajemen }\end{array}$ & 0.011 & 0.005 & 0.003 & 0.011 & 0.019 & 0.003 \\
\hline $\begin{array}{l}\text { Sekolah Tinggi } \\
\text { Ilmu Ekonomi } \\
\text { Sabang }\end{array}$ & 0.041 & 0.071 & 0.004 & 0.041 & 0.234 & 0.005 \\
\hline $\begin{array}{l}\text { STMIK } \\
\text { Abulyatama }\end{array}$ & 0.022 & 0.039 & 0.226 & 0.022 & 0.024 & 0.003 \\
\hline $\begin{array}{l}\text { Sekolah Tinggi } \\
\text { Ilmu Kehutanan } \\
\text { Pante Kulu }\end{array}$ & 0.017 & 0.002 & 0.002 & 0.017 & 0.026 & 0.003 \\
\hline $\begin{array}{l}\text { Sekolah Tinggi } \\
\text { Ilmu } \\
\text { Administrasi } \\
\text { Iskandar Thani }\end{array}$ & 0.011 & 0.000 & 0.002 & 0.011 & 0.005 & 0.003 \\
\hline
\end{tabular}

\begin{tabular}{|c|c|c|c|c|c|c|}
\hline $\begin{array}{l}\text { Sekolah Tinggi } \\
\text { Teknik Iskandar } \\
\text { Thani }\end{array}$ & 0.019 & 0.003 & 0.002 & 0.019 & 0.000 & 0.142 \\
\hline $\begin{array}{l}\text { Sekolah Tinggi } \\
\text { Ilmu } \\
\text { Manajemen Pase }\end{array}$ & 0.019 & 0.029 & 0.215 & 0.019 & 0.044 & 0.003 \\
\hline $\begin{array}{l}\text { Sekolah Tinggi } \\
\text { Ilmu Ekonomi } \\
\text { YPHB }\end{array}$ & 0.008 & 0.039 & 0.380 & 0.008 & 0.005 & 0.003 \\
\hline $\begin{array}{lr}\text { Sekolah } & \text { Tinggi } \\
\text { Teknik } & \text { Bina } \\
\text { Cendikia } & \end{array}$ & 0.013 & 0.006 & 0.003 & 0.013 & 0.000 & 0.142 \\
\hline \begin{tabular}{l} 
Sekolah Tinggi \\
Ilmu Hukum \\
Muhammadiyah \\
\multicolumn{2}{l}{ Takengon }
\end{tabular} & 0.017 & 0.022 & 0.003 & 0.017 & 0.118 & 0.005 \\
\hline $\begin{array}{ll}\text { STMIK } & \text { Bina } \\
\text { Bangsa } & \\
\end{array}$ & 0.056 & 0.000 & 0.141 & 0.056 & 0.000 & 0.142 \\
\hline $\begin{array}{l}\text { Sekolah Tinggi } \\
\text { Ilmu } \\
\text { Manajemen } \\
\text { Indonesia } \\
\text { Meulaboh }\end{array}$ & 0.028 & 0.040 & 0.004 & 0.028 & 0.000 & 0.142 \\
\hline $\begin{array}{l}\text { Sekolah Tinggi } \\
\text { Ilmu Psikologi } \\
\text { Harapan Bangsa }\end{array}$ & 0.017 & 0.005 & 0.003 & 0.017 & 0.000 & 0.142 \\
\hline $\begin{array}{l}\text { Sekolah Tinggi } \\
\text { Ilmu } \\
\text { Administrasi } \\
\text { Nasional } \\
\end{array}$ & 0.022 & 0.027 & 0.003 & 0.022 & 0.057 & 0.003 \\
\hline $\begin{array}{ll}\text { STKIP } & \text { Al- } \\
\text { Washliyah } & \\
\end{array}$ & 0.025 & 0.064 & 0.004 & 0.025 & 0.000 & 0.142 \\
\hline $\begin{array}{l}\text { STKIP An-nur } \\
\text { Nangro Aceh }\end{array}$ & 0.025 & 0.028 & 0.003 & 0.025 & 0.042 & 0.003 \\
\hline $\begin{array}{l}\text { STKIP Bina } \\
\text { Bangsa } \\
\text { Getsempena } \\
\end{array}$ & 0.107 & 0.098 & 0.003 & 0.107 & 0.146 & 0.003 \\
\hline $\begin{array}{l}\text { Sekolah Tinggi } \\
\text { Ilmu Pertanian } \\
\text { Yashafa } \\
\end{array}$ & 0.031 & 0.037 & 0.003 & 0.031 & 0.081 & 0.003 \\
\hline $\begin{array}{l}\text { STKIP } \\
\text { Muhammadiyah } \\
\text { Aceh Tengah }\end{array}$ & 0.027 & 0.005 & 0.002 & 0.027 & 0.003 & 0.002 \\
\hline $\begin{array}{l}\text { Sekolah Tinggi } \\
\text { Ilmu Kesehatan } \\
\text { Harapan Bangsa }\end{array}$ & 0.041 & 0.002 & 0.002 & 0.041 & 0.026 & 0.003 \\
\hline $\begin{array}{l}\text { STIKES Payung } \\
\text { Negeri Aceh } \\
\text { Darussalam }\end{array}$ & 0.030 & 0.032 & 0.003 & 0.030 & 0.000 & 0.142 \\
\hline $\begin{array}{ll}\text { STISIP } & \text { Al } \\
\text { Washliyah } & \\
\text { Banda Aceh } & \end{array}$ & 0.003 & 0.001 & 0.003 & 0.003 & 0.010 & 0.218 \\
\hline $\begin{array}{l}\text { STIE Bumi } \\
\text { Persada } \\
\text { Lhokseumawe }\end{array}$ & 0.061 & 0.026 & 0.003 & 0.061 & 0.072 & 0.003 \\
\hline $\begin{array}{lr}\text { STIKES } & \text { Cut } \\
\text { Nyak } & \text { Dhien } \\
\text { Langsa } & \\
\end{array}$ & 0.049 & 0.032 & 0.003 & 0.049 & 0.053 & 0.003 \\
\hline $\begin{array}{l}\text { Sekolah Tinggi } \\
\text { Ilmu Ekonomi } \\
\text { Lhokseumawe }\end{array}$ & 0.042 & 0.017 & 0.160 & 0.042 & 0.027 & 0.003 \\
\hline $\begin{array}{l}\text { Sekolah Tinggi } \\
\text { Ilmu Kesehatan } \\
\text { Langsa } \\
\end{array}$ & 0.002 & 0.006 & 0.316 & 0.002 & 0.000 & 0.142 \\
\hline $\begin{array}{l}\text { STIKES } \\
\text { Darussalam } \\
\text { Lhokseumawe }\end{array}$ & 0.038 & 0.059 & 0.004 & 0.038 & 0.000 & 0.142 \\
\hline $\begin{array}{l}\text { STIKES } \\
\text { Muhammadiyah } \\
\text { Lhokseumawe }\end{array}$ & 0.033 & 0.058 & 0.004 & 0.033 & 0.107 & 0.004 \\
\hline $\begin{array}{l}\text { STIKES Medika } \\
\text { Seramoe Barat }\end{array}$ & 0.027 & 0.012 & 0.003 & 0.027 & 0.017 & 0.003 \\
\hline $\begin{array}{l}\text { STIKES } \\
\text { Darussalam } \\
\text { Lhokseumawe }\end{array}$ & 0.038 & 0.059 & 0.004 & 0.038 & 0.000 & 0.142 \\
\hline $\begin{array}{l}\text { STIKES } \\
\text { Muhammadiyah } \\
\text { Lhokseumawe }\end{array}$ & 0.033 & 0.058 & 0.004 & 0.033 & 0.107 & 0.004 \\
\hline $\begin{array}{l}\text { STIKES Medika } \\
\text { Seramoe Barat }\end{array}$ & 0.027 & 0.012 & 0.003 & 0.027 & 0.017 & 0.003 \\
\hline $\begin{array}{l}\text { STIKES Medika } \\
\text { Nurul Islam }\end{array}$ & 0.052 & 0.057 & 0.003 & 0.052 & 0.000 & 0.142 \\
\hline $\begin{array}{ll}\text { Sekolah } & \text { Tinggi } \\
\text { Ilmu } & \end{array}$ & 0.034 & 0.040 & 0.003 & 0.034 & 0.083 & 0.003 \\
\hline
\end{tabular}




\begin{tabular}{|c|c|c|c|c|c|c|}
\hline $\begin{array}{l}\text { Administrasi } \\
\text { Pelita Nusantara }\end{array}$ & & & & & & \\
\hline $\begin{array}{l}\text { STIKES Bumi } \\
\text { Persada } \\
\text { Lhokseumawe }\end{array}$ & 0.024 & 0.027 & 0.003 & 0.024 & 0.000 & 0.142 \\
\hline $\begin{array}{l}\text { STIKES } \\
\text { Getsempena } \\
\text { Lhoksukon }\end{array}$ & 0.069 & 0.021 & 0.003 & 0.069 & 0.037 & 0.003 \\
\hline $\begin{array}{ll}\text { STIKES Bina } \\
\text { Nusantara }\end{array}$ & 0.045 & 0.021 & 0.003 & 0.045 & 0.000 & 0.142 \\
\hline $\begin{array}{l}\text { Sekolah Tinggi } \\
\text { Ilmu Ekonomi } \\
\text { Kebangsaan } \\
\text { Bireuen }\end{array}$ & 0.041 & 0.080 & 0.236 & 0.041 & 0.000 & 0.142 \\
\hline $\begin{array}{l}\text { STKIP } \\
\text { Muhammadiyah } \\
\text { Aceh Barat Daya }\end{array}$ & 0.038 & 0.069 & 0.004 & 0.038 & 0.120 & 0.004 \\
\hline $\begin{array}{ll}\text { STIKES Nurul } \\
\text { Hasanah } & \\
\text { Kutacane } & \end{array}$ & 0.082 & 0.054 & 0.003 & 0.082 & 0.081 & 0.003 \\
\hline $\begin{array}{ll}\text { STKIP } & \text { Bina } \\
\text { Bangsa } & \\
\text { Meulaboh } & \end{array}$ & 0.083 & 0.059 & 0.003 & 0.083 & 0.076 & 0.003 \\
\hline $\begin{array}{l}\text { STKIP Usman } \\
\text { Safri Kutacane }\end{array}$ & 0.013 & 0.023 & 0.229 & 0.013 & 0.053 & 0.004 \\
\hline $\begin{array}{l}\text { STKIP Bumi } \\
\text { Persada } \\
\text { Lhokseumawe }\end{array}$ & 0.019 & 0.022 & 0.003 & 0.019 & 0.065 & 0.004 \\
\hline $\begin{array}{l}\text { STIKES Medika } \\
\text { Teuku Umar }\end{array}$ & 0.000 & 0.004 & 0.141 & 0.000 & 0.015 & 0.142 \\
\hline $\begin{array}{ll}\text { STIKES } & \\
\text { Bustanul Ulum } \\
\text { Langsa }\end{array}$ & 0.045 & 0.010 & 0.003 & 0.045 & 0.024 & 0.003 \\
\hline $\begin{array}{l}\text { STMIK } \\
\text { Indonesia Banda } \\
\text { Aceh }\end{array}$ & 0.022 & 0.014 & 0.003 & 0.022 & 0.026 & 0.003 \\
\hline $\begin{array}{ll}\text { STKIP } & \text { Citra } \\
\text { Bangsa } & \text { Aceh } \\
\text { Utara } & \end{array}$ & 0.013 & 0.012 & 0.003 & 0.013 & 0.029 & 0.003 \\
\hline $\begin{array}{l}\text { Sekolah Tinggi } \\
\text { Manajemen } \\
\text { Informatika dan } \\
\text { Komputer } \\
\text { Harapan Ibu }\end{array}$ & 0.020 & 0.001 & 0.002 & 0.020 & 0.004 & 0.002 \\
\hline $\begin{array}{l}\text { AMIK } \\
\text { Indonesia }\end{array}$ & 0.033 & 0.075 & 0.004 & 0.033 & 0.054 & 0.003 \\
\hline $\begin{array}{l}\text { Akademi } \\
\text { Pariwisata } \\
\text { Muhammadiyah } \\
\text { Banda Aceh }\end{array}$ & 0.009 & 0.000 & 0.002 & 0.009 & 0.009 & 0.003 \\
\hline $\begin{array}{l}\text { Akademi } \\
\text { Keuangan } \\
\text { Perbankan } \\
\text { Nusantara }\end{array}$ & 0.016 & 0.049 & 0.005 & 0.016 & 0.140 & 0.006 \\
\hline $\begin{array}{ll}\text { AMIK } & \text { Jabal } \\
\text { Ghafur }\end{array}$ & 0.005 & 0.002 & 0.003 & 0.005 & 0.000 & 0.002 \\
\hline $\begin{array}{l}\text { Akademi } \\
\text { Maritim } \\
\text { Nusantara } \\
\text { Malahayati }\end{array}$ & 0.014 & 0.000 & 0.141 & 0.014 & 0.000 & 0.142 \\
\hline $\begin{array}{l}\text { Akademi } \\
\text { Maritim Aceh } \\
\text { Darussalam }\end{array}$ & 0.005 & 0.069 & 0.014 & 0.005 & 0.007 & 0.003 \\
\hline $\begin{array}{l}\text { Akademi } \\
\text { Perikanan Dan } \\
\text { Ilmu Kelautan }\end{array}$ & 0.034 & 0.000 & 0.141 & 0.034 & 0.000 & 0.142 \\
\hline $\begin{array}{l}\text { Akademi } \\
\text { Kebidanan } \\
\text { Darussalam }\end{array}$ & 0.030 & 0.009 & 0.003 & 0.030 & 0.000 & 0.142 \\
\hline $\begin{array}{l}\text { Akademi } \\
\text { Keperawatan } \\
\text { Yappkes Aceh } \\
\text { Singkil }\end{array}$ & 0.009 & 0.005 & 0.003 & 0.009 & 0.000 & 0.142 \\
\hline $\begin{array}{l}\text { Akademi } \\
\text { Keperawatan } \\
\text { Teungku } \\
\text { Fakinah Banda } \\
\text { Aceh }\end{array}$ & 0.027 & 0.000 & 0.141 & 0.027 & 0.000 & 0.142 \\
\hline $\begin{array}{l}\text { Akademi } \\
\text { Kebidanan } \\
\text { Public Health } \\
\text { Medical Nursing }\end{array}$ & 0.013 & 0.005 & 0.003 & 0.013 & 0.000 & 0.142 \\
\hline $\begin{array}{l}\text { Akademi } \\
\text { Kebidanan } \\
\text { Saleha }\end{array}$ & 0.030 & 0.006 & 0.003 & 0.030 & 0.012 & 0.003 \\
\hline
\end{tabular}

\begin{tabular}{|c|c|c|c|c|c|c|}
\hline $\begin{array}{ll}\text { Akademi } & \\
\text { Kebidanan } & \\
\text { Harapan } & \text { Ibu } \\
\text { Langsa } & \\
\end{array}$ & 0.014 & 0.012 & 0.003 & 0.014 & 0.023 & 0.003 \\
\hline $\begin{array}{l}\text { Akademi } \\
\text { Kebidanan } \\
\text { Nurul Hasanah }\end{array}$ & 0.039 & 0.007 & 0.002 & 0.039 & 0.013 & 0.002 \\
\hline $\begin{array}{l}\text { Akademi } \\
\text { Kebidanan } \\
\text { Yayasan } \\
\text { Pendidikan } \\
\text { Mona }\end{array}$ & 0.009 & 0.003 & 0.003 & 0.009 & 0.005 & 0.003 \\
\hline $\begin{array}{l}\text { Akademi } \\
\text { Kebidanan } \\
\text { Medica Putro } \\
\text { Bungsu }\end{array}$ & 0.020 & 0.001 & 0.002 & 0.020 & 0.002 & 0.002 \\
\hline $\begin{array}{l}\text { Akademi } \\
\text { Kebidanan } \\
\text { Nadhirah } \\
\end{array}$ & 0.013 & 0.000 & 0.141 & 0.013 & 0.000 & 0.142 \\
\hline $\begin{array}{l}\text { Akademik } \\
\text { Teknik } \\
\text { Otomotif Banda } \\
\text { Aceh }\end{array}$ & 0.000 & 0.000 & 0.141 & 0.000 & 0.000 & 0.142 \\
\hline $\begin{array}{l}\text { Akademi } \\
\text { Kebidanan } \\
\text { Medica Bakti } \\
\text { Persada }\end{array}$ & 0.028 & 0.000 & 0.141 & 0.028 & 0.010 & 0.003 \\
\hline $\begin{array}{l}\text { Akademi } \\
\text { Kebidanan } \\
\text { Munawarrah } \\
\text { Bireuen }\end{array}$ & 0.024 & 0.010 & 0.003 & 0.024 & 0.021 & 0.003 \\
\hline $\begin{array}{l}\text { Akademi } \\
\text { Kebidanan } \\
\text { Yayasan } \\
\text { Pendidikan } \\
\text { Mona }\end{array}$ & 0.009 & 0.003 & 0.003 & 0.009 & 0.005 & 0.003 \\
\hline $\begin{array}{l}\text { Akademi } \\
\text { Kebidanan } \\
\text { Medica Putro } \\
\text { Bungsu }\end{array}$ & 0.020 & 0.001 & 0.002 & 0.020 & 0.002 & 0.002 \\
\hline $\begin{array}{l}\text { Akademi } \\
\text { Kebidanan } \\
\text { Nadhirah }\end{array}$ & 0.013 & 0.000 & 0.141 & 0.013 & 0.000 & 0.142 \\
\hline $\begin{array}{l}\text { Akademik } \\
\text { Teknik } \\
\text { Otomotif Banda } \\
\text { Aceh }\end{array}$ & 0.000 & 0.000 & 0.141 & 0.000 & 0.000 & 0.142 \\
\hline $\begin{array}{l}\text { Akademi } \\
\text { Kebidanan } \\
\text { Medica Bakti } \\
\text { Persada }\end{array}$ & 0.028 & 0.000 & 0.141 & 0.028 & 0.010 & 0.003 \\
\hline $\begin{array}{l}\text { Akademi } \\
\text { Kebidanan } \\
\text { Munawarrah } \\
\text { Bireuen }\end{array}$ & 0.024 & 0.010 & 0.003 & 0.024 & 0.021 & 0.003 \\
\hline $\begin{array}{l}\text { Akademi } \\
\text { Fisioterapi } \\
\text { Harapan Bangsa } \\
\text { Banda Aceh }\end{array}$ & 0.006 & 0.002 & 0.003 & 0.006 & 0.005 & 0.003 \\
\hline $\begin{array}{lr}\text { Akademi } & \text { Analis } \\
\text { Farmasi Dan } \\
\text { Makanan Banda } \\
\text { Aceh }\end{array}$ & 0.020 & 0.016 & 0.003 & 0.020 & 0.030 & 0.003 \\
\hline $\begin{array}{l}\text { Akademi } \\
\text { Kebidanan Gayo } \\
\text { Lues }\end{array}$ & 0.022 & 0.000 & 0.141 & 0.022 & 0.000 & 0.142 \\
\hline $\begin{array}{l}\text { Akademi } \\
\text { Kebidanan } \\
\text { Adhira Mustika } \\
\text { Gayo }\end{array}$ & 0.003 & 0.002 & 0.003 & 0.003 & 0.000 & 0.142 \\
\hline $\begin{array}{l}\text { Akademi } \\
\text { Kebidanan } \\
\text { Darul Husada }\end{array}$ & 0.020 & 0.016 & 0.003 & 0.020 & 0.039 & 0.003 \\
\hline $\begin{array}{l}\text { Akademi } \\
\text { Kebidanan } \\
\text { Bunga Bangsa } \\
\text { Idi }\end{array}$ & 0.008 & 0.004 & 0.003 & 0.008 & 0.006 & 0.003 \\
\hline $\begin{array}{l}\text { Akademi } \\
\text { Kebidanan } \\
\text { Medica Alas } \\
\text { Leuser }\end{array}$ & 0.017 & 0.000 & 0.141 & 0.017 & 0.000 & 0.142 \\
\hline $\begin{array}{l}\text { Akademi } \\
\text { Keperawatan } \\
\text { Ibnu Sina Kota } \\
\text { Sabang }\end{array}$ & 0.013 & 0.005 & 0.003 & 0.013 & 0.012 & 0.003 \\
\hline
\end{tabular}




\begin{tabular}{|c|c|c|c|c|c|c|}
\hline $\begin{array}{l}\text { Akademi } \\
\text { Kebidanan Pidie } \\
\text { Jaya } \\
\end{array}$ & 0.013 & 0.002 & 0.002 & 0.013 & 0.000 & 0.142 \\
\hline $\begin{array}{l}\text { Akademi } \\
\text { Farmasi YPPM } \\
\text { Mandiri }\end{array}$ & 0.014 & 0.012 & 0.003 & 0.014 & 0.019 & 0.173 \\
\hline $\begin{array}{ll}\text { Akademi } & \\
\text { Kebidanan } & \\
\text { Medika } & \text { Sri } \\
\text { Tamiang } & \\
\end{array}$ & 0.008 & 0.002 & 0.003 & 0.008 & 0.000 & 0.142 \\
\hline $\begin{array}{l}\text { Akademi } \\
\text { Kebidanan } \\
\text { Muhammadiyah } \\
\text { Banda Aceh }\end{array}$ & 0.019 & 0.018 & 0.003 & 0.019 & 0.042 & 0.003 \\
\hline $\begin{array}{l}\text { Akademi } \\
\text { Keperawatan } \\
\text { Abulyatama }\end{array}$ & 0.019 & 0.007 & 0.003 & 0.019 & 0.011 & 0.003 \\
\hline $\begin{array}{l}\text { Akademi } \\
\text { Keperawatan } \\
\text { Kesdam } \\
\text { Iskandar Muda } \\
\text { Lhokseumawe }\end{array}$ & 0.019 & 0.008 & 0.003 & 0.019 & 0.022 & 0.003 \\
\hline $\begin{array}{l}\text { Akademi } \\
\text { Keperawatan } \\
\text { Kesdam } \\
\text { Iskandar Muda } \\
\text { Banda Aceh } \\
\end{array}$ & 0.019 & 0.025 & 0.003 & 0.019 & 0.076 & 0.234 \\
\hline $\begin{array}{l}\text { Akademi } \\
\text { Kesehatan } \\
\text { Lingkungan } \\
\text { Jabal Ghafur }\end{array}$ & 0.003 & 0.007 & 0.004 & 0.003 & 0.013 & 0.004 \\
\hline $\begin{array}{l}\text { Akademi } \\
\text { Keperawatan } \\
\text { Jabal Ghafur }\end{array}$ & 0.011 & 0.030 & 0.005 & 0.011 & 0.063 & 0.005 \\
\hline $\begin{array}{l}\text { Akademi } \\
\text { kebidanan } \\
\text { Meuligoe Nur } \\
\text { Amin } \\
\end{array}$ & 0.002 & 0.004 & 0.262 & 0.002 & 0.000 & 0.142 \\
\hline $\begin{array}{l}\text { Akademi } \\
\text { Perekam dan } \\
\text { Info Kes Sihat } \\
\text { Beurata }\end{array}$ & 0.016 & 0.005 & 0.158 & 0.016 & 0.013 & 0.003 \\
\hline $\begin{array}{l}\text { Akademi Teknik } \\
\text { Elektromedik } \\
\text { Kupula Aceh }\end{array}$ & 0.011 & 0.005 & 0.003 & 0.011 & 0.011 & 0.003 \\
\hline $\begin{array}{l}\text { Akademi } \\
\text { Kebidanan } \\
\text { Medika } \\
\text { Anugerah Tasya }\end{array}$ & 0.000 & 0.000 & 0.141 & 0.000 & 0.000 & 0.142 \\
\hline $\begin{array}{l}\text { Akademi Teknik } \\
\text { Radiodiagnostik } \\
\text { Dan Radioterapi } \\
\text { (ATRO) Banda } \\
\text { Aceh }\end{array}$ & 0.013 & 0.009 & 0.003 & 0.013 & 0.021 & 0.003 \\
\hline $\begin{array}{l}\text { Akademi } \\
\text { Fisioterapi } \\
\text { Muhammadiyah } \\
\text { Aceh }\end{array}$ & 0.000 & 0.003 & 0.141 & 0.000 & 0.004 & 0.142 \\
\hline $\begin{array}{l}\text { Akademi } \\
\text { Keperawatan } \\
\text { Muhammadiyah } \\
\text { Bireuen }\end{array}$ & 0.008 & 0.010 & 0.003 & 0.008 & 0.000 & 0.142 \\
\hline $\begin{array}{l}\text { Akademi } \\
\text { Manajemen } \\
\text { Gunung Leuser }\end{array}$ & 0.000 & 0.000 & 0.141 & 0.000 & 0.000 & 0.142 \\
\hline Politeknik Aceh & 0.083 & 0.027 & 0.003 & 0.083 & 0.051 & 0.003 \\
\hline $\begin{array}{l}\text { Politeknik } \\
\text { Indonesia } \\
\text { Venezuela }\end{array}$ & 0.045 & 0.029 & 0.003 & 0.045 & 0.050 & 0.003 \\
\hline $\begin{array}{l}\text { Politeknik Aceh } \\
\text { Selatan }\end{array}$ & 0.056 & 0.029 & 0.003 & 0.056 & 0.103 & 0.003 \\
\hline $\begin{array}{l}\text { Politeknik } \\
\text { Kutaraja }\end{array}$ & 0.000 & 0.000 & 0.141 & 0.000 & 0.000 & 0.142 \\
\hline
\end{tabular}

Menghitung jarak setiap alternatif dengan solusi ideal positif dan negative, serta nilai preferensi untuk setiap alternative dan pada tahap ini juga tahapan terakhir dari metode ini yaitu menghitung nilai preferensi dari masing-masing alternatif (Vi) guna mendapatkan hasil akhir, nilai Vi yang paling tinggi menunjukkan alternatif terbaik yang terpilih untuk Perguruan Tinggi yang terbaik.

Tabel 3. Matriks Keputusan Bobot dan Hasil

\begin{tabular}{|c|c|c|c|c|c|c|c|c|c|c|}
\hline \multirow{4}{*}{$\begin{array}{c}\text { Altern } \\
\text { atif }\end{array}$} & \multicolumn{6}{|c|}{ Kriteria } & \multirow{4}{*}{$\mathrm{D}+$} & \multirow{4}{*}{ D- } & \multirow{4}{*}{ v } & \multirow{4}{*}{$\begin{array}{c}\mathrm{Ha} \\
\text { sil } \\
\text { / } \\
\mathrm{Ra} \\
\text { ng } \\
\text { kin } \\
\mathrm{g}\end{array}$} \\
\hline & 3 & 2 & 5 & 3 & 2 & 5 & & & & \\
\hline & \multicolumn{3}{|c|}{$2016 / 2017$} & \multicolumn{3}{|c|}{$2017 / 2018$} & & & & \\
\hline & $\begin{array}{c}\text { Dos } \\
\text { en } \\
\text { Teta } \\
\text { p }\end{array}$ & $\begin{array}{l}\text { Ma } \\
\text { hasi } \\
\text { swa }\end{array}$ & $\begin{array}{c}\text { Rasi } \\
\text { o }\end{array}$ & $\begin{array}{c}\text { Dos } \\
\text { en } \\
\text { Teta } \\
\text { p }\end{array}$ & $\begin{array}{l}\text { Ma } \\
\text { hasi } \\
\text { swa }\end{array}$ & $\begin{array}{c}\text { Rasi } \\
\text { o }\end{array}$ & & & & \\
\hline $\begin{array}{l}\text { Universita } \\
\text { s Jabal } \\
\text { Ghafur }\end{array}$ & $\begin{array}{l}1.13 \\
8\end{array}$ & $\begin{array}{l}0.52 \\
9\end{array}$ & $\begin{array}{l}0.01 \\
5\end{array}$ & $\begin{array}{l}1.13 \\
8\end{array}$ & $\begin{array}{l}0.00 \\
0\end{array}$ & $\begin{array}{l}0.71 \\
0\end{array}$ & $\begin{array}{r}1.95 \\
1\end{array}$ & $\begin{array}{r}2.57 \\
5\end{array}$ & $\begin{array}{r}0.56 \\
9\end{array}$ & 4 \\
\hline $\begin{array}{l}\text { Universita } \\
\text { s Iskandar } \\
\text { Muda }\end{array}$ & $\begin{array}{l}0.61 \\
1\end{array}$ & $\begin{array}{l}0.26 \\
3\end{array}$ & $\begin{array}{l}0.01 \\
4\end{array}$ & $\begin{array}{l}0.61 \\
1\end{array}$ & $\begin{array}{l}0.04 \\
3\end{array}$ & $\begin{array}{l}0.72 \\
2\end{array}$ & $\begin{array}{r}2.30 \\
7\end{array}$ & $\begin{array}{r}2.13 \\
8\end{array}$ & $\begin{array}{r}0.48 \\
1\end{array}$ & 8 \\
\hline $\begin{array}{l}\text { Universita } \\
\mathrm{s} \\
\text { Abulyata } \\
\mathrm{ma}\end{array}$ & $\begin{array}{l}1.06 \\
8\end{array}$ & $\begin{array}{l}0.46 \\
7\end{array}$ & $\begin{array}{l}0.01 \\
4\end{array}$ & $\begin{array}{l}1.06 \\
8\end{array}$ & $\begin{array}{l}0.00 \\
0\end{array}$ & $\begin{array}{l}0.71 \\
0\end{array}$ & $\begin{array}{r}1.99 \\
7\end{array}$ & $\begin{array}{r}2.50 \\
2\end{array}$ & $\begin{array}{r}0.55 \\
6\end{array}$ & 5 \\
\hline $\begin{array}{l}\text { Universita } \\
\mathrm{s} \\
\text { Muhamm } \\
\text { adiyah } \\
\text { Aceh }\end{array}$ & $\begin{array}{l}0.78 \\
1\end{array}$ & $\begin{array}{l}0.89 \\
6\end{array}$ & $\begin{array}{l}1.12 \\
0\end{array}$ & $\begin{array}{l}0.78 \\
1\end{array}$ & $\begin{array}{l}1.65 \\
5\end{array}$ & $\begin{array}{l}0.01 \\
8\end{array}$ & $\begin{array}{r}1.49 \\
2\end{array}$ & $\begin{array}{r}2.58 \\
8\end{array}$ & $\begin{array}{r}0.63 \\
4\end{array}$ & 2 \\
\hline $\begin{array}{l}\text { Universita } \\
\text { s Serambi } \\
\text { Mekkah }\end{array}$ & $\begin{array}{l}1.46 \\
7\end{array}$ & $\begin{array}{l}0.81 \\
1\end{array}$ & $\begin{array}{l}0.01 \\
5\end{array}$ & $\begin{array}{l}1.46 \\
7\end{array}$ & $\begin{array}{l}0.00 \\
0\end{array}$ & $\begin{array}{l}0.71 \\
0\end{array}$ & $\begin{array}{r}1.82 \\
4\end{array}$ & $\begin{array}{r}2.95 \\
4\end{array}$ & $\begin{array}{r}0.61 \\
8\end{array}$ & 3 \\
\hline $\begin{array}{l}\text { Universita } \\
\text { s Al } \\
\text { Muslim }\end{array}$ & $\begin{array}{l}0.95 \\
0\end{array}$ & $\begin{array}{l}1.13 \\
2\end{array}$ & $\begin{array}{l}0.01 \\
9\end{array}$ & $\begin{array}{l}0.95 \\
0\end{array}$ & $\begin{array}{l}0.30 \\
0\end{array}$ & $\begin{array}{l}0.01 \\
3\end{array}$ & $\begin{array}{r}1.54 \\
0\end{array}$ & $\begin{array}{r}2.83 \\
7\end{array}$ & $\begin{array}{r}0.64 \\
8\end{array}$ & 1 \\
\hline $\begin{array}{l}\text { Universita } \\
\text { s Gajah } \\
\text { Putih }\end{array}$ & $\begin{array}{l}0.34 \\
8\end{array}$ & $\begin{array}{l}0.16 \\
2\end{array}$ & $\begin{array}{l}0.01 \\
5\end{array}$ & $\begin{array}{l}0.34 \\
8\end{array}$ & $\begin{array}{l}0.00 \\
0\end{array}$ & $\begin{array}{l}0.71 \\
0\end{array}$ & $\begin{array}{r}2.58 \\
3\end{array}$ & $\begin{array}{r}2.00 \\
7\end{array}$ & $\begin{array}{r}0.43 \\
7\end{array}$ & 58 \\
\hline $\begin{array}{l}\text { Universita } \\
\text { s Gunung } \\
\text { Leuser } \\
\text { Aceh }\end{array}$ & $\begin{array}{l}0.28 \\
2\end{array}$ & $\begin{array}{l}0.23 \\
1\end{array}$ & $\begin{array}{l}1.00 \\
2\end{array}$ & $\begin{array}{l}0.28 \\
2\end{array}$ & $\begin{array}{l}0.43 \\
7\end{array}$ & $\begin{array}{l}0.01 \\
6\end{array}$ & $\begin{array}{r}2.46 \\
7\end{array}$ & $\begin{array}{r}1.59 \\
4\end{array}$ & $\begin{array}{r}0.39 \\
2\end{array}$ & 86 \\
\hline $\begin{array}{l}\text { Universita } \\
\mathrm{s} \\
\text { Ubudiyah } \\
\text { Indonesia }\end{array}$ & $\begin{array}{l}0.43 \\
7\end{array}$ & $\begin{array}{l}0.16 \\
6\end{array}$ & $\begin{array}{l}0.01 \\
4\end{array}$ & $\begin{array}{l}0.43 \\
7\end{array}$ & $\begin{array}{l}0.00 \\
7\end{array}$ & $\begin{array}{l}0.01 \\
2\end{array}$ & $\begin{array}{r}2.40 \\
2\end{array}$ & $\begin{array}{r}2.30 \\
3\end{array}$ & $\begin{array}{r}0.49 \\
0\end{array}$ & 7 \\
\hline $\begin{array}{l}\text { Universita } \\
\text { s Sains } \\
\text { Cut Nyak } \\
\text { Dhien }\end{array}$ & $\begin{array}{l}0.29 \\
6\end{array}$ & $\begin{array}{l}0.05 \\
1\end{array}$ & $\begin{array}{l}0.01 \\
3\end{array}$ & $\begin{array}{l}0.29 \\
6\end{array}$ & $\begin{array}{l}0.15 \\
4\end{array}$ & $\begin{array}{l}0.01 \\
3\end{array}$ & $\begin{array}{r}2.48 \\
3\end{array}$ & $\begin{array}{r}2.25 \\
8\end{array}$ & $\begin{array}{r}0.47 \\
6\end{array}$ & 10 \\
\hline $\begin{array}{l}\text { Sekolah } \\
\text { Tinggi } \\
\text { Ilmu } \\
\text { Ekonomi } \\
\text { Indonesia } \\
\text { Banda } \\
\text { Aceh }\end{array}$ & $\begin{array}{l}0.10 \\
8\end{array}$ & $\begin{array}{l}0.07 \\
7\end{array}$ & $\begin{array}{l}0.01 \\
6\end{array}$ & $\begin{array}{l}0.10 \\
8\end{array}$ & $\begin{array}{l}0.00 \\
0\end{array}$ & $\begin{array}{l}0.71 \\
0\end{array}$ & $\begin{array}{r}2.83 \\
5\end{array}$ & $\begin{array}{r}1.94 \\
5\end{array}$ & $\begin{array}{r}0.40 \\
7\end{array}$ & 70 \\
\hline $\begin{array}{l}\text { Sekolah } \\
\text { Tinggi } \\
\text { Ilmu } \\
\text { Manajeme } \\
\mathrm{n}\end{array}$ & $\begin{array}{l}0.03 \\
3\end{array}$ & $\begin{array}{l}0.00 \\
9\end{array}$ & $\begin{array}{l}0.01 \\
3\end{array}$ & $\begin{array}{l}0.03 \\
3\end{array}$ & $\begin{array}{l}0.03 \\
9\end{array}$ & $\begin{array}{l}0.01 \\
5\end{array}$ & $\begin{array}{r}2.82 \\
6\end{array}$ & $\begin{array}{r}2.21 \\
2\end{array}$ & $\begin{array}{r}0.43 \\
9\end{array}$ & 53 \\
\hline $\begin{array}{l}\text { Sekolah } \\
\text { Tinggi } \\
\text { Ilmu } \\
\text { Ekonomi } \\
\text { Sabang }\end{array}$ & $\begin{array}{l}0.12 \\
2\end{array}$ & $\begin{array}{l}0.14 \\
2\end{array}$ & $\begin{array}{l}0.01 \\
9\end{array}$ & $\begin{array}{l}0.12 \\
2\end{array}$ & $\begin{array}{l}0.46 \\
8\end{array}$ & $\begin{array}{l}0.02 \\
3\end{array}$ & $\begin{array}{r}2.45 \\
1\end{array}$ & $\begin{array}{r}2.26 \\
3\end{array}$ & $\begin{array}{r}0.48 \\
0\end{array}$ & 9 \\
\hline $\begin{array}{l}\text { STMIK } \\
\text { Abulyata } \\
\text { ma }\end{array}$ & $\begin{array}{l}0.06 \\
6\end{array}$ & $\begin{array}{l}0.07 \\
8\end{array}$ & $\begin{array}{l}1.13 \\
2\end{array}$ & $\begin{array}{l}0.06 \\
6\end{array}$ & $\begin{array}{l}0.04 \\
8\end{array}$ & $\begin{array}{l}0.01 \\
4\end{array}$ & $\begin{array}{r}2.98 \\
0\end{array}$ & $\begin{array}{r}1.39 \\
4\end{array}$ & $\begin{array}{r}0.31 \\
9\end{array}$ & 94 \\
\hline $\begin{array}{l}\text { Sekolah } \\
\text { Tinggi } \\
\text { Ilmu } \\
\text { Kehutana } \\
\text { n Pante } \\
\text { Kulu }\end{array}$ & $\begin{array}{l}0.05 \\
2\end{array}$ & $\begin{array}{l}0.00 \\
4\end{array}$ & $\begin{array}{l}0.01 \\
2\end{array}$ & $\begin{array}{l}0.05 \\
2\end{array}$ & $\begin{array}{l}0.05 \\
2\end{array}$ & $\begin{array}{l}0.01 \\
5\end{array}$ & $\begin{array}{r}2.80 \\
2\end{array}$ & $\begin{array}{r}2.21 \\
4\end{array}$ & $\begin{array}{r}0.44 \\
1\end{array}$ & 45 \\
\hline $\begin{array}{l}\text { Sekolah } \\
\text { Tinggi } \\
\text { Ilmu } \\
\text { Administr } \\
\text { asi } \\
\text { Iskandar } \\
\text { Thani }\end{array}$ & $\begin{array}{l}0.03 \\
3\end{array}$ & $\begin{array}{l}0.00 \\
0\end{array}$ & $\begin{array}{l}0.01 \\
2\end{array}$ & $\begin{array}{l}0.03 \\
3\end{array}$ & $\begin{array}{l}0.00 \\
9\end{array}$ & $\begin{array}{l}0.01 \\
3\end{array}$ & $\begin{array}{r}2.84 \\
7\end{array}$ & $\begin{array}{r}2.21 \\
4\end{array}$ & $\begin{array}{r}0.43 \\
8\end{array}$ & 56 \\
\hline $\begin{array}{l}\text { Sekolah } \\
\text { Tinggi } \\
\text { Teknik } \\
\text { Iskandar } \\
\text { Thani } \\
\end{array}$ & $\begin{array}{l}0.05 \\
6\end{array}$ & $\begin{array}{l}0.00 \\
6\end{array}$ & $\begin{array}{l}0.01 \\
2\end{array}$ & $\begin{array}{l}0.05 \\
6\end{array}$ & $\begin{array}{l}0.00 \\
0\end{array}$ & $\begin{array}{l}0.71 \\
0\end{array}$ & $\begin{array}{r}2.91 \\
1\end{array}$ & $\begin{array}{r}1.94 \\
3\end{array}$ & $\begin{array}{r}0.40 \\
0\end{array}$ & 76 \\
\hline $\begin{array}{l}\text { Sekolah } \\
\text { Tinggi }\end{array}$ & $\begin{array}{l}0.05 \\
6\end{array}$ & $\begin{array}{l}0.05 \\
7\end{array}$ & $\begin{array}{l}1.07 \\
3\end{array}$ & $\begin{array}{l}0.05 \\
6\end{array}$ & $\begin{array}{l}0.08 \\
8\end{array}$ & $\begin{array}{l}0.01 \\
6\end{array}$ & $\begin{array}{r}2.95 \\
2\end{array}$ & $\begin{array}{r}1.42 \\
6\end{array}$ & $\begin{array}{r}0.32 \\
6\end{array}$ & 93 \\
\hline
\end{tabular}




\begin{tabular}{|c|c|c|c|c|c|c|c|c|c|c|}
\hline $\begin{array}{l}\text { Ilmu } \\
\text { Manajeme } \\
\text { n Pase }\end{array}$ & & & & & & & & & & \\
\hline $\begin{array}{l}\text { Sekolah } \\
\text { Tinggi } \\
\text { Ilmu } \\
\text { Ekonomi } \\
\text { YPHB }\end{array}$ & $\begin{array}{l}0.02 \\
4\end{array}$ & $\begin{array}{l}0.07 \\
8\end{array}$ & $\begin{array}{l}1.89 \\
8\end{array}$ & $\begin{array}{l}0.02 \\
4\end{array}$ & $\begin{array}{l}0.01 \\
0\end{array}$ & $\begin{array}{l}0.01 \\
3\end{array}$ & $\begin{array}{r}3.39 \\
8\end{array}$ & $\begin{array}{r}1.16 \\
1\end{array}$ & $\begin{array}{r}0.25 \\
5\end{array}$ & $\begin{array}{l}11 \\
1\end{array}$ \\
\hline $\begin{array}{l}\text { Sekolah } \\
\text { Tinggi } \\
\text { Teknik } \\
\text { Bina } \\
\text { Cendikia }\end{array}$ & $\begin{array}{l}0.03 \\
8\end{array}$ & $\begin{array}{l}0.01 \\
2\end{array}$ & $\begin{array}{l}0.01 \\
4\end{array}$ & $\begin{array}{l}0.03 \\
8\end{array}$ & $\begin{array}{l}0.00 \\
0\end{array}$ & $\begin{array}{l}0.71 \\
0\end{array}$ & $\begin{array}{r}2.92 \\
7\end{array}$ & $\begin{array}{r}1.94 \\
1\end{array}$ & $\begin{array}{r}0.39 \\
9\end{array}$ & 78 \\
\hline $\begin{array}{l}\text { Sekolah } \\
\text { Tinggi } \\
\text { Ilmu } \\
\text { Hukum } \\
\text { Muhamm } \\
\text { adiyah } \\
\text { Takengon }\end{array}$ & $\begin{array}{l}0.05 \\
2\end{array}$ & $\begin{array}{l}0.04 \\
3\end{array}$ & $\begin{array}{l}0.01 \\
7\end{array}$ & $\begin{array}{l}0.05 \\
2\end{array}$ & $\begin{array}{l}0.23 \\
6\end{array}$ & $\begin{array}{l}0.02 \\
5\end{array}$ & $\begin{array}{r}2.68 \\
5\end{array}$ & $\begin{array}{r}2.21 \\
7\end{array}$ & $\begin{array}{r}0.45 \\
2\end{array}$ & 26 \\
\hline $\begin{array}{l}\text { STMIK } \\
\text { Bina } \\
\text { Bangsa }\end{array}$ & $\begin{array}{l}0.16 \\
9\end{array}$ & $\begin{array}{l}0.00 \\
0\end{array}$ & $\begin{array}{l}0.70 \\
7\end{array}$ & $\begin{array}{l}0.16 \\
9\end{array}$ & $\begin{array}{l}0.00 \\
0\end{array}$ & $\begin{array}{l}0.71 \\
0\end{array}$ & $\begin{array}{r}2.89 \\
2\end{array}$ & $\begin{array}{r}1.29 \\
9\end{array}$ & $\begin{array}{r}0.31 \\
0\end{array}$ & 96 \\
\hline $\begin{array}{l}\text { Sekolah } \\
\text { Tinggi } \\
\text { Ilmu } \\
\text { Manajeme } \\
\mathrm{n} \\
\text { Indonesia } \\
\text { Meulaboh }\end{array}$ & $\begin{array}{l}0.08 \\
5\end{array}$ & $\begin{array}{l}0.08 \\
1\end{array}$ & $\begin{array}{l}0.01 \\
8\end{array}$ & $\begin{array}{l}0.08 \\
5\end{array}$ & $\begin{array}{l}0.00 \\
0\end{array}$ & $\begin{array}{l}0.71 \\
0\end{array}$ & $\begin{array}{r}2.85 \\
6\end{array}$ & $\begin{array}{r}1.94 \\
2\end{array}$ & $\begin{array}{r}0.40 \\
5\end{array}$ & 72 \\
\hline $\begin{array}{l}\text { Sekolah } \\
\text { Tinggi } \\
\text { Ilmu } \\
\text { Psikologi } \\
\text { Harapan } \\
\text { Bangsa }\end{array}$ & $\begin{array}{l}0.05 \\
2\end{array}$ & $\begin{array}{l}0.00 \\
9\end{array}$ & $\begin{array}{l}0.01 \\
3\end{array}$ & $\begin{array}{l}0.05 \\
2\end{array}$ & $\begin{array}{l}0.00 \\
0\end{array}$ & $\begin{array}{l}0.71 \\
0\end{array}$ & $\begin{array}{r}2.91 \\
5\end{array}$ & $\begin{array}{r}1.94 \\
2\end{array}$ & $\begin{array}{r}0.40 \\
0\end{array}$ & 77 \\
\hline $\begin{array}{l}\text { Sekolah } \\
\text { Tinggi } \\
\text { Ilmu } \\
\text { Administr } \\
\text { asi } \\
\text { Nasional }\end{array}$ & $\begin{array}{l}0.06 \\
6\end{array}$ & $\begin{array}{l}0.05 \\
5\end{array}$ & $\begin{array}{l}0.01 \\
7\end{array}$ & $\begin{array}{l}0.06 \\
6\end{array}$ & $\begin{array}{l}0.11 \\
4\end{array}$ & $\begin{array}{l}0.01 \\
7\end{array}$ & $\begin{array}{r}2.73 \\
2\end{array}$ & $\begin{array}{r}2.21 \\
3\end{array}$ & $\begin{array}{r}0.44 \\
7\end{array}$ & 29 \\
\hline $\begin{array}{l}\text { STKIP } \\
\text { Al- } \\
\text { Washliyah }\end{array}$ & $\begin{array}{l}0.07 \\
5\end{array}$ & $\begin{array}{l}0.12 \\
7\end{array}$ & $\begin{array}{l}0.02 \\
2\end{array}$ & $\begin{array}{l}0.07 \\
5\end{array}$ & $\begin{array}{l}0.00 \\
0\end{array}$ & $\begin{array}{l}0.71 \\
0\end{array}$ & $\begin{array}{r}2.84 \\
8\end{array}$ & $\begin{array}{r}1.93 \\
9\end{array}$ & $\begin{array}{r}0.40 \\
5\end{array}$ & 71 \\
\hline $\begin{array}{l}\text { STKIP } \\
\text { An-nur } \\
\text { Nangro } \\
\text { Aceh }\end{array}$ & $\begin{array}{l}0.07 \\
5\end{array}$ & $\begin{array}{l}0.05 \\
6\end{array}$ & $\begin{array}{l}0.01 \\
6\end{array}$ & $\begin{array}{l}0.07 \\
5\end{array}$ & $\begin{array}{l}0.08 \\
4\end{array}$ & $\begin{array}{l}0.01 \\
5\end{array}$ & $\begin{array}{r}2.73 \\
9\end{array}$ & $\begin{array}{r}2.21 \\
4\end{array}$ & $\begin{array}{r}0.44 \\
7\end{array}$ & 31 \\
\hline $\begin{array}{l}\text { STKIP } \\
\text { Bina } \\
\text { Bangsa } \\
\text { Getsempe } \\
\text { na }\end{array}$ & $\begin{array}{l}0.32 \\
0\end{array}$ & $\begin{array}{l}0.19 \\
7\end{array}$ & $\begin{array}{l}0.01 \\
5\end{array}$ & $\begin{array}{l}0.32 \\
0\end{array}$ & $\begin{array}{l}0.29 \\
3\end{array}$ & $\begin{array}{l}0.01 \\
4\end{array}$ & $\begin{array}{r}2.31 \\
6\end{array}$ & $\begin{array}{r}2.28 \\
3\end{array}$ & $\begin{array}{r}0.49 \\
6\end{array}$ & 6 \\
\hline $\begin{array}{l}\text { Sekolah } \\
\text { Tinggi } \\
\text { Ilmu } \\
\text { Pertanian } \\
\text { Yashafa }\end{array}$ & $\begin{array}{l}0.09 \\
4\end{array}$ & $\begin{array}{l}0.07 \\
4\end{array}$ & $\begin{array}{l}0.01 \\
6\end{array}$ & $\begin{array}{l}0.09 \\
4\end{array}$ & $\begin{array}{l}0.16 \\
2\end{array}$ & $\begin{array}{l}0.01 \\
7\end{array}$ & $\begin{array}{r}2.66 \\
8\end{array}$ & $\begin{array}{r}2.21 \\
9\end{array}$ & $\begin{array}{r}0.45 \\
4\end{array}$ & 25 \\
\hline $\begin{array}{l}\text { STKIP } \\
\text { Muhamm } \\
\text { adiyah } \\
\text { Aceh } \\
\text { Tengah }\end{array}$ & $\begin{array}{l}0.08 \\
0\end{array}$ & $\begin{array}{l}0.00 \\
9\end{array}$ & $\begin{array}{l}0.01 \\
2\end{array}$ & $\begin{array}{l}0.08 \\
0\end{array}$ & $\begin{array}{l}0.00 \\
7\end{array}$ & $\begin{array}{l}0.01 \\
2\end{array}$ & $\begin{array}{r}2.79 \\
8\end{array}$ & $\begin{array}{r}2.21 \\
6\end{array}$ & $\begin{array}{r}0.44 \\
2\end{array}$ & 43 \\
\hline $\begin{array}{l}\text { Sekolah } \\
\text { Tinggi } \\
\text { Ilmu } \\
\text { Kesehatan } \\
\text { Harapan } \\
\text { Bangsa }\end{array}$ & $\begin{array}{l}0.12 \\
2\end{array}$ & $\begin{array}{l}0.00 \\
5\end{array}$ & $\begin{array}{l}0.01 \\
2\end{array}$ & $\begin{array}{l}0.12 \\
2\end{array}$ & $\begin{array}{l}0.05 \\
3\end{array}$ & $\begin{array}{l}0.01 \\
3\end{array}$ & $\begin{array}{r}2.73 \\
1\end{array}$ & $\begin{array}{r}2.22 \\
1\end{array}$ & $\begin{array}{r}0.44 \\
9\end{array}$ & 28 \\
\hline $\begin{array}{l}\text { STIKES } \\
\text { Payung } \\
\text { Negeri } \\
\text { Aceh } \\
\text { Darussala } \\
\text { m }\end{array}$ & $\begin{array}{l}0.08 \\
9\end{array}$ & $\begin{array}{l}0.06 \\
3\end{array}$ & $\begin{array}{l}0.01 \\
6\end{array}$ & $\begin{array}{l}0.08 \\
9\end{array}$ & $\begin{array}{l}0.00 \\
0\end{array}$ & $\begin{array}{l}0.71 \\
0\end{array}$ & $\begin{array}{r}2.85 \\
8\end{array}$ & $\begin{array}{r}1.94 \\
3\end{array}$ & $\begin{array}{r}0.40 \\
5\end{array}$ & 73 \\
\hline $\begin{array}{l}\text { STISIP Al } \\
\text { Washliyah } \\
\text { Banda } \\
\text { Aceh }\end{array}$ & $\begin{array}{l}0.00 \\
9\end{array}$ & $\begin{array}{l}0.00 \\
2\end{array}$ & $\begin{array}{l}0.01 \\
3\end{array}$ & $\begin{array}{l}0.00 \\
9\end{array}$ & $\begin{array}{l}0.02 \\
1\end{array}$ & $\begin{array}{l}1.08 \\
8\end{array}$ & $\begin{array}{r}3.05 \\
9\end{array}$ & $\begin{array}{r}1.88 \\
7\end{array}$ & $\begin{array}{r}0.38 \\
2\end{array}$ & 88 \\
\hline $\begin{array}{l}\text { STIE } \\
\text { Bumi } \\
\text { Persada } \\
\text { Lhokseu } \\
\text { mawe }\end{array}$ & $\begin{array}{l}0.18 \\
3\end{array}$ & $\begin{array}{l}0.05 \\
2\end{array}$ & $\begin{array}{l}0.01 \\
3\end{array}$ & $\begin{array}{l}0.18 \\
3\end{array}$ & $\begin{array}{l}0.14 \\
5\end{array}$ & $\begin{array}{l}0.01 \\
4\end{array}$ & $\begin{array}{r}2.59 \\
7\end{array}$ & $\begin{array}{r}2.23 \\
2\end{array}$ & $\begin{array}{r}0.46 \\
2\end{array}$ & 16 \\
\hline $\begin{array}{l}\text { STIKES } \\
\text { Cut Nyak } \\
\text { Dhien } \\
\text { Langsa }\end{array}$ & $\begin{array}{l}0.14 \\
6\end{array}$ & $\begin{array}{l}0.06 \\
4\end{array}$ & $\begin{array}{l}0.01 \\
4\end{array}$ & $\begin{array}{l}0.14 \\
6\end{array}$ & $\begin{array}{l}0.10 \\
6\end{array}$ & $\begin{array}{l}0.01 \\
4\end{array}$ & $\begin{array}{r}2.65 \\
2\end{array}$ & $\begin{array}{r}2.22 \\
4\end{array}$ & $\begin{array}{r}0.45 \\
6\end{array}$ & 20 \\
\hline $\begin{array}{l}\text { Sekolah } \\
\text { Tinggi } \\
\text { Ilmu } \\
\text { Ekonomi } \\
\text { Lhokseu } \\
\text { mawe }\end{array}$ & $\begin{array}{l}0.12 \\
7\end{array}$ & $\begin{array}{l}0.03 \\
3\end{array}$ & $\begin{array}{l}0.80 \\
2\end{array}$ & $\begin{array}{l}0.12 \\
7\end{array}$ & $\begin{array}{l}0.05 \\
3\end{array}$ & $\begin{array}{l}0.01 \\
3\end{array}$ & $\begin{array}{r}2.82 \\
7\end{array}$ & $\begin{array}{r}1.60 \\
6\end{array}$ & $\begin{array}{r}0.36 \\
2\end{array}$ & 91 \\
\hline $\begin{array}{l}\text { Sekolah } \\
\text { Tinggi } \\
\text { Ilmu }\end{array}$ & $\begin{array}{l}0.00 \\
5\end{array}$ & $\begin{array}{l}0.01 \\
1\end{array}$ & $\begin{array}{l}1.58 \\
0\end{array}$ & $\begin{array}{l}0.00 \\
5\end{array}$ & $\begin{array}{l}0.00 \\
0\end{array}$ & $\begin{array}{l}0.71 \\
0\end{array}$ & $\begin{array}{r}3.35 \\
0\end{array}$ & $\begin{array}{r}0.56 \\
1\end{array}$ & $\begin{array}{r}0.14 \\
3\end{array}$ & $\begin{array}{l}11 \\
4\end{array}$ \\
\hline
\end{tabular}

\begin{tabular}{|c|c|c|c|c|c|c|c|c|c|c|}
\hline $\begin{array}{l}\text { Kesehatan } \\
\text { Langsa }\end{array}$ & & & & & & & & & & \\
\hline $\begin{array}{l}\text { STIKES } \\
\text { Darussala } \\
\mathrm{m} \\
\text { Lhokseu } \\
\text { mawe }\end{array}$ & $\begin{array}{l}0.11 \\
3\end{array}$ & $\begin{array}{l}0.11 \\
9\end{array}$ & $\begin{array}{l}0.01 \\
8\end{array}$ & $\begin{array}{l}0.11 \\
3\end{array}$ & $\begin{array}{l}0.00 \\
0\end{array}$ & $\begin{array}{l}0.71 \\
0\end{array}$ & $\begin{array}{r}2.81 \\
5\end{array}$ & $\begin{array}{r}1.94 \\
6\end{array}$ & $\begin{array}{r}0.40 \\
9\end{array}$ & 68 \\
\hline $\begin{array}{l}\text { STIKES } \\
\text { Muhamm } \\
\text { adiyah } \\
\text { Lhokseu } \\
\text { mawe }\end{array}$ & $\begin{array}{l}0.09 \\
9\end{array}$ & $\begin{array}{l}0.11 \\
6\end{array}$ & $\begin{array}{l}0.01 \\
9\end{array}$ & $\begin{array}{l}0.09 \\
9\end{array}$ & $\begin{array}{l}0.21 \\
4\end{array}$ & $\begin{array}{l}0.01 \\
8\end{array}$ & $\begin{array}{r}2.61 \\
8\end{array}$ & $\begin{array}{r}2.22 \\
3\end{array}$ & $\begin{array}{r}0.45 \\
9\end{array}$ & 18 \\
\hline $\begin{array}{l}\text { STIKES } \\
\text { Medika } \\
\text { Seramoe } \\
\text { Barat }\end{array}$ & $\begin{array}{l}0.08 \\
0\end{array}$ & $\begin{array}{l}0.02 \\
4\end{array}$ & $\begin{array}{l}0.01 \\
4\end{array}$ & $\begin{array}{l}0.08 \\
0\end{array}$ & $\begin{array}{l}0.03 \\
5\end{array}$ & $\begin{array}{l}0.01 \\
3\end{array}$ & $\begin{array}{r}2.77 \\
5\end{array}$ & $\begin{array}{r}2.21 \\
5\end{array}$ & $\begin{array}{r}0.44 \\
4\end{array}$ & 37 \\
\hline $\begin{array}{l}\text { STIKES } \\
\text { Darussala } \\
\mathrm{m} \\
\text { Lhokseu } \\
\text { mawe }\end{array}$ & $\begin{array}{l}0.11 \\
3\end{array}$ & $\begin{array}{l}0.11 \\
9\end{array}$ & $\begin{array}{l}0.01 \\
8\end{array}$ & $\begin{array}{l}0.11 \\
3\end{array}$ & $\begin{array}{l}0.00 \\
0\end{array}$ & $\begin{array}{l}0.71 \\
0\end{array}$ & $\begin{array}{r}2.81 \\
5\end{array}$ & $\begin{array}{r}1.94 \\
6\end{array}$ & $\begin{array}{r}0.40 \\
9\end{array}$ & 68 \\
\hline $\begin{array}{l}\text { STIKES } \\
\text { Muhamm } \\
\text { adiyah } \\
\text { Lhokseu } \\
\text { mawe }\end{array}$ & $\begin{array}{l}0.09 \\
9\end{array}$ & $\begin{array}{l}0.11 \\
6\end{array}$ & $\begin{array}{l}0.01 \\
9\end{array}$ & $\begin{array}{l}0.09 \\
9\end{array}$ & $\begin{array}{l}0.21 \\
4\end{array}$ & $\begin{array}{l}0.01 \\
8\end{array}$ & $\begin{array}{r}2.61 \\
8\end{array}$ & $\begin{array}{r}2.22 \\
3\end{array}$ & $\begin{array}{r}0.45 \\
9\end{array}$ & 18 \\
\hline $\begin{array}{l}\text { STIKES } \\
\text { Medika } \\
\text { Seramoe } \\
\text { Barat }\end{array}$ & $\begin{array}{l}0.08 \\
0\end{array}$ & $\begin{array}{l}0.02 \\
4\end{array}$ & $\begin{array}{l}0.01 \\
4\end{array}$ & $\begin{array}{l}0.08 \\
0\end{array}$ & $\begin{array}{l}0.03 \\
5\end{array}$ & $\begin{array}{l}0.01 \\
3\end{array}$ & $\begin{array}{r}2.77 \\
5\end{array}$ & $\begin{array}{r}2.21 \\
5\end{array}$ & $\begin{array}{r}0.44 \\
4\end{array}$ & 37 \\
\hline $\begin{array}{l}\text { STIKES } \\
\text { Medika } \\
\text { Nurul } \\
\text { Islam } \\
\end{array}$ & $\begin{array}{l}0.15 \\
5\end{array}$ & $\begin{array}{l}0.11 \\
4\end{array}$ & $\begin{array}{l}0.01 \\
6\end{array}$ & $\begin{array}{l}0.15 \\
5\end{array}$ & $\begin{array}{l}0.00 \\
0\end{array}$ & $\begin{array}{l}0.71 \\
0\end{array}$ & $\begin{array}{r}2.77 \\
6\end{array}$ & $\begin{array}{r}1.95 \\
3\end{array}$ & $\begin{array}{r}0.41 \\
3\end{array}$ & 66 \\
\hline $\begin{array}{l}\text { Sekolah } \\
\text { Tinggi } \\
\text { Ilmu } \\
\text { Administr } \\
\text { asi Pelita } \\
\text { Nusantara }\end{array}$ & $\begin{array}{l}0.10 \\
3\end{array}$ & $\begin{array}{l}0.08 \\
0\end{array}$ & $\begin{array}{l}0.01 \\
6\end{array}$ & $\begin{array}{l}0.10 \\
3\end{array}$ & $\begin{array}{l}0.16 \\
5\end{array}$ & $\begin{array}{l}0.01 \\
6\end{array}$ & $\begin{array}{r}2.65 \\
5\end{array}$ & $\begin{array}{r}2.22 \\
0\end{array}$ & $\begin{array}{r}0.45 \\
5\end{array}$ & 22 \\
\hline $\begin{array}{l}\text { STIKES } \\
\text { Bumi } \\
\text { Persada } \\
\text { Lhokseu } \\
\text { mawe }\end{array}$ & $\begin{array}{l}0.07 \\
1\end{array}$ & $\begin{array}{l}0.05 \\
4\end{array}$ & $\begin{array}{l}0.01 \\
6\end{array}$ & $\begin{array}{l}0.07 \\
1\end{array}$ & $\begin{array}{l}0.00 \\
0\end{array}$ & $\begin{array}{l}0.71 \\
0\end{array}$ & $\begin{array}{r}2.87 \\
9\end{array}$ & $\begin{array}{r}1.94 \\
1\end{array}$ & $\begin{array}{r}0.40 \\
3\end{array}$ & 75 \\
\hline $\begin{array}{l}\text { STIKES } \\
\text { Getsempe } \\
\text { na } \\
\text { Lhoksuko } \\
\text { n }\end{array}$ & $\begin{array}{l}0.20 \\
7\end{array}$ & $\begin{array}{l}0.04 \\
2\end{array}$ & $\begin{array}{l}0.01 \\
3\end{array}$ & $\begin{array}{l}0.20 \\
7\end{array}$ & $\begin{array}{l}0.07 \\
4\end{array}$ & $\begin{array}{l}0.01 \\
3\end{array}$ & $\begin{array}{r}2.62 \\
0\end{array}$ & $\begin{array}{r}2.23 \\
4\end{array}$ & $\begin{array}{r}0.46 \\
0\end{array}$ & 17 \\
\hline $\begin{array}{l}\text { STIKES } \\
\text { Bina } \\
\text { Nusantara }\end{array}$ & $\begin{array}{l}0.13 \\
6\end{array}$ & $\begin{array}{l}0.04 \\
3\end{array}$ & $\begin{array}{l}0.01 \\
4\end{array}$ & $\begin{array}{l}0.13 \\
6\end{array}$ & $\begin{array}{l}0.00 \\
0\end{array}$ & $\begin{array}{l}0.71 \\
0\end{array}$ & $\begin{array}{r}2.82 \\
1\end{array}$ & $\begin{array}{r}1.95 \\
0\end{array}$ & $\begin{array}{r}0.40 \\
9\end{array}$ & 67 \\
\hline $\begin{array}{l}\text { Sekolah } \\
\text { Tinggi } \\
\text { Ilmu } \\
\text { Ekonomi } \\
\text { Kebangsa } \\
\text { an } \\
\text { Bireuen }\end{array}$ & $\begin{array}{l}0.12 \\
2\end{array}$ & $\begin{array}{l}0.16 \\
0\end{array}$ & $\begin{array}{l}1.17 \\
9\end{array}$ & $\begin{array}{l}0.12 \\
2\end{array}$ & $\begin{array}{l}0.00 \\
0\end{array}$ & $\begin{array}{l}0.71 \\
0\end{array}$ & $\begin{array}{r}3.02 \\
5\end{array}$ & $\begin{array}{r}0.88 \\
6\end{array}$ & $\begin{array}{r}0.22 \\
7\end{array}$ & $\begin{array}{l}11 \\
2\end{array}$ \\
\hline $\begin{array}{l}\text { STKIP } \\
\text { Muhamm } \\
\text { adiyah } \\
\text { Aceh } \\
\text { Barat } \\
\text { Daya }\end{array}$ & $\begin{array}{l}0.11 \\
3\end{array}$ & $\begin{array}{l}0.13 \\
9\end{array}$ & $\begin{array}{l}0.01 \\
9\end{array}$ & $\begin{array}{l}0.11 \\
3\end{array}$ & $\begin{array}{l}0.24 \\
0\end{array}$ & $\begin{array}{l}0.01 \\
8\end{array}$ & $\begin{array}{r}2.58 \\
1\end{array}$ & $\begin{array}{r}2.22 \\
8\end{array}$ & $\begin{array}{r}0.46 \\
3\end{array}$ & 15 \\
\hline $\begin{array}{l}\text { STIKES } \\
\text { Nurul } \\
\text { Hasanah } \\
\text { Kutacane }\end{array}$ & $\begin{array}{l}0.24 \\
5\end{array}$ & $\begin{array}{l}0.10 \\
8\end{array}$ & $\begin{array}{l}0.01 \\
4\end{array}$ & $\begin{array}{l}0.24 \\
5\end{array}$ & $\begin{array}{l}0.16 \\
2\end{array}$ & $\begin{array}{l}0.01 \\
4\end{array}$ & $\begin{array}{r}2.50 \\
4\end{array}$ & $\begin{array}{r}2.24 \\
6\end{array}$ & $\begin{array}{r}0.47 \\
3\end{array}$ & 12 \\
\hline $\begin{array}{l}\text { STKIP } \\
\text { Bina } \\
\text { Bangsa } \\
\text { Meulaboh }\end{array}$ & $\begin{array}{l}0.24 \\
9\end{array}$ & $\begin{array}{l}0.11 \\
8\end{array}$ & $\begin{array}{l}0.01 \\
5\end{array}$ & $\begin{array}{l}0.24 \\
9\end{array}$ & $\begin{array}{l}0.15 \\
2\end{array}$ & $\begin{array}{l}0.01 \\
4\end{array}$ & $\begin{array}{r}2.50 \\
1\end{array}$ & $\begin{array}{r}2.24 \\
7\end{array}$ & $\begin{array}{r}0.47 \\
3\end{array}$ & 11 \\
\hline $\begin{array}{l}\text { STKIP } \\
\text { Usman } \\
\text { Safri } \\
\text { Kutacane } \\
\end{array}$ & $\begin{array}{l}0.03 \\
8\end{array}$ & $\begin{array}{l}0.04 \\
6\end{array}$ & $\begin{array}{l}1.14 \\
4\end{array}$ & $\begin{array}{l}0.03 \\
8\end{array}$ & $\begin{array}{l}0.10 \\
7\end{array}$ & $\begin{array}{l}0.02 \\
0\end{array}$ & $\begin{array}{r}2.99 \\
1\end{array}$ & $\begin{array}{r}1.38 \\
2\end{array}$ & $\begin{array}{r}0.31 \\
6\end{array}$ & 95 \\
\hline $\begin{array}{l}\text { STKIP } \\
\text { Bumi } \\
\text { Persada } \\
\text { Lhokseu } \\
\text { mawe } \\
\end{array}$ & $\begin{array}{l}0.05 \\
6\end{array}$ & $\begin{array}{l}0.04 \\
4\end{array}$ & $\begin{array}{l}0.01 \\
6\end{array}$ & $\begin{array}{l}0.05 \\
6\end{array}$ & $\begin{array}{l}0.13 \\
0\end{array}$ & $\begin{array}{l}0.01 \\
8\end{array}$ & $\begin{array}{r}2.73 \\
7\end{array}$ & $\begin{array}{r}2.21 \\
2\end{array}$ & $\begin{array}{r}0.44 \\
7\end{array}$ & 30 \\
\hline $\begin{array}{l}\text { STIKES } \\
\text { Medika } \\
\text { Teuku } \\
\text { Umar }\end{array}$ & $\begin{array}{l}0.00 \\
0\end{array}$ & $\begin{array}{l}0.00 \\
7\end{array}$ & $\begin{array}{l}0.70 \\
7\end{array}$ & $\begin{array}{l}0.00 \\
0\end{array}$ & $\begin{array}{l}0.03 \\
0\end{array}$ & $\begin{array}{l}0.71 \\
0\end{array}$ & $\begin{array}{r}3.03 \\
0\end{array}$ & $\begin{array}{r}1.27 \\
7\end{array}$ & $\begin{array}{r}0.29 \\
7\end{array}$ & $\begin{array}{l}10 \\
4\end{array}$ \\
\hline $\begin{array}{l}\text { STIKES } \\
\text { Bustanul } \\
\text { Ulum } \\
\text { Langsa }\end{array}$ & $\begin{array}{l}0.13 \\
6\end{array}$ & $\begin{array}{l}0.02 \\
0\end{array}$ & $\begin{array}{l}0.01 \\
3\end{array}$ & $\begin{array}{l}0.13 \\
6\end{array}$ & $\begin{array}{l}0.04 \\
8\end{array}$ & $\begin{array}{l}0.01 \\
3\end{array}$ & $\begin{array}{r}2.71 \\
3\end{array}$ & $\begin{array}{r}2.22 \\
2\end{array}$ & $\begin{array}{r}0.45 \\
0\end{array}$ & 27 \\
\hline $\begin{array}{l}\text { STMIK } \\
\text { Indonesia } \\
\text { Banda } \\
\text { Aceh }\end{array}$ & $\begin{array}{l}0.06 \\
6\end{array}$ & $\begin{array}{l}0.02 \\
9\end{array}$ & $\begin{array}{l}0.01 \\
4\end{array}$ & $\begin{array}{l}0.06 \\
6\end{array}$ & $\begin{array}{l}0.05 \\
1\end{array}$ & $\begin{array}{l}0.01 \\
4\end{array}$ & $\begin{array}{r}2.77 \\
8\end{array}$ & $\begin{array}{r}2.21 \\
4\end{array}$ & $\begin{array}{r}0.44 \\
3\end{array}$ & 40 \\
\hline $\begin{array}{l}\text { STKIP } \\
\text { Citra } \\
\text { Bangsa }\end{array}$ & $\begin{array}{l}0.03 \\
8\end{array}$ & $\begin{array}{l}0.02 \\
3\end{array}$ & $\begin{array}{l}0.01 \\
6\end{array}$ & $\begin{array}{l}0.03 \\
8\end{array}$ & $\begin{array}{l}0.05 \\
8\end{array}$ & $\begin{array}{l}0.01 \\
6\end{array}$ & $\begin{array}{r}2.80 \\
5\end{array}$ & $\begin{array}{r}2.21 \\
0\end{array}$ & $\begin{array}{r}0.44 \\
1\end{array}$ & 46 \\
\hline
\end{tabular}




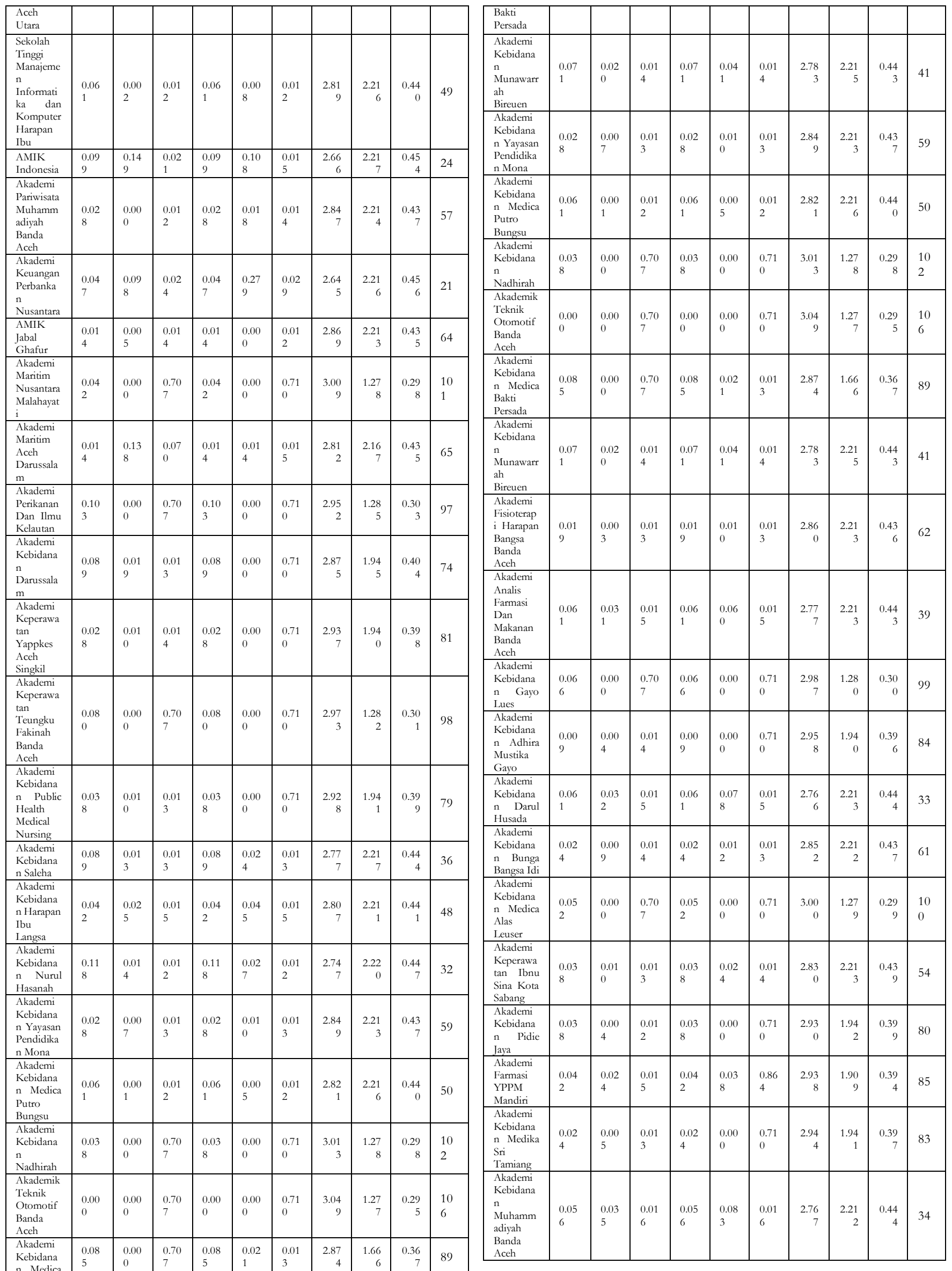




\begin{tabular}{|c|c|c|c|c|c|c|c|c|c|c|}
\hline $\begin{array}{l}\text { Akademi } \\
\text { Keperawa } \\
\text { tan } \\
\text { Abulyata } \\
\text { ma } \\
\end{array}$ & $\begin{array}{l}0.05 \\
6\end{array}$ & $\begin{array}{l}0.01 \\
3\end{array}$ & $\begin{array}{l}0.01 \\
3\end{array}$ & $\begin{array}{l}0.05 \\
6\end{array}$ & $\begin{array}{l}0.02 \\
2\end{array}$ & $\begin{array}{l}0.01 \\
3\end{array}$ & $\begin{array}{r}2.81 \\
1\end{array}$ & $\begin{array}{r}2.21 \\
4\end{array}$ & $\begin{array}{r}0.44 \\
1\end{array}$ & 47 \\
\hline $\begin{array}{l}\text { Akademi } \\
\text { Keperawa } \\
\text { tan } \\
\text { Kesdam } \\
\text { Iskandar } \\
\text { Muda } \\
\text { Lhokseu } \\
\text { mawe }\end{array}$ & $\begin{array}{l}0.05 \\
6\end{array}$ & $\begin{array}{l}0.01 \\
6\end{array}$ & $\begin{array}{l}0.01 \\
4\end{array}$ & $\begin{array}{l}0.05 \\
6\end{array}$ & $\begin{array}{l}0.04 \\
4\end{array}$ & $\begin{array}{l}0.01 \\
4\end{array}$ & $\begin{array}{r}2.79 \\
7\end{array}$ & $\begin{array}{r}2.21 \\
3\end{array}$ & $\begin{array}{r}0.44 \\
2\end{array}$ & 44 \\
\hline $\begin{array}{l}\text { Akademi } \\
\text { Keperawa } \\
\text { tan } \\
\text { Kesdam } \\
\text { Iskandar } \\
\text { Muda } \\
\text { Banda } \\
\text { Aceh }\end{array}$ & $\begin{array}{l}0.05 \\
6\end{array}$ & $\begin{array}{l}0.04 \\
9\end{array}$ & $\begin{array}{l}0.01 \\
7\end{array}$ & $\begin{array}{l}0.05 \\
6\end{array}$ & $\begin{array}{l}0.15 \\
1\end{array}$ & $\begin{array}{l}1.17 \\
1\end{array}$ & $\begin{array}{r}2.96 \\
0\end{array}$ & $\begin{array}{r}1.89 \\
0\end{array}$ & $\begin{array}{r}0.39 \\
0\end{array}$ & 87 \\
\hline $\begin{array}{l}\text { Akademi } \\
\text { Kesehatan } \\
\text { Lingkung } \\
\text { an Jabal } \\
\text { Ghafur }\end{array}$ & $\begin{array}{l}0.00 \\
9\end{array}$ & $\begin{array}{l}0.01 \\
5\end{array}$ & $\begin{array}{l}0.02 \\
1\end{array}$ & $\begin{array}{l}0.00 \\
9\end{array}$ & $\begin{array}{l}0.02 \\
7\end{array}$ & $\begin{array}{l}0.02 \\
0\end{array}$ & $\begin{array}{r}2.85 \\
5\end{array}$ & $\begin{array}{r}2.20 \\
2\end{array}$ & $\begin{array}{r}0.43 \\
5\end{array}$ & 63 \\
\hline $\begin{array}{l}\text { Akademi } \\
\text { Keperawa } \\
\text { tan Jabal } \\
\text { Ghafur } \\
\end{array}$ & $\begin{array}{l}0.03 \\
3\end{array}$ & $\begin{array}{l}0.05 \\
9\end{array}$ & $\begin{array}{l}0.02 \\
3\end{array}$ & $\begin{array}{l}0.03 \\
3\end{array}$ & $\begin{array}{l}0.12 \\
6\end{array}$ & $\begin{array}{l}0.02 \\
3\end{array}$ & $\begin{array}{r}2.75 \\
8\end{array}$ & $\begin{array}{r}2.20 \\
4\end{array}$ & $\begin{array}{r}0.44 \\
4\end{array}$ & 35 \\
\hline $\begin{array}{l}\text { Akademi } \\
\text { kebidanan } \\
\text { Meuligoe } \\
\text { Nur Amin }\end{array}$ & $\begin{array}{l}0.00 \\
5\end{array}$ & $\begin{array}{l}0.00 \\
8\end{array}$ & $\begin{array}{l}1.30 \\
9\end{array}$ & $\begin{array}{l}0.00 \\
5\end{array}$ & $\begin{array}{l}0.00 \\
0\end{array}$ & $\begin{array}{l}0.71 \\
0\end{array}$ & $\begin{array}{r}3.23 \\
3\end{array}$ & $\begin{array}{r}0.74 \\
9\end{array}$ & $\begin{array}{r}0.18 \\
8\end{array}$ & $\begin{array}{l}11 \\
3\end{array}$ \\
\hline $\begin{array}{l}\text { Akademi } \\
\text { Perekam } \\
\text { dan Info } \\
\text { Kes Sihat } \\
\text { Beurata }\end{array}$ & $\begin{array}{l}0.04 \\
7\end{array}$ & $\begin{array}{l}0.01 \\
1\end{array}$ & $\begin{array}{l}0.79 \\
0\end{array}$ & $\begin{array}{l}0.04 \\
7\end{array}$ & $\begin{array}{l}0.02 \\
6\end{array}$ & $\begin{array}{l}0.01 \\
3\end{array}$ & $\begin{array}{r}2.92 \\
5\end{array}$ & $\begin{array}{r}1.60 \\
4\end{array}$ & $\begin{array}{r}0.35 \\
4\end{array}$ & 92 \\
\hline $\begin{array}{l}\text { Akademi } \\
\text { Teknik } \\
\text { Elektrom } \\
\text { edik } \\
\text { Kupula } \\
\text { Aceh }\end{array}$ & $\begin{array}{l}0.03 \\
3\end{array}$ & $\begin{array}{l}0.00 \\
9\end{array}$ & $\begin{array}{l}0.01 \\
3\end{array}$ & $\begin{array}{l}0.03 \\
3\end{array}$ & $\begin{array}{l}0.02 \\
2\end{array}$ & $\begin{array}{l}0.01 \\
4\end{array}$ & $\begin{array}{r}2.83 \\
6\end{array}$ & $\begin{array}{r}2.21 \\
2\end{array}$ & $\begin{array}{r}0.43 \\
8\end{array}$ & 55 \\
\hline $\begin{array}{l}\text { Akademi } \\
\text { Kebidana } \\
\text { n Medika } \\
\text { Anugerah } \\
\text { Tasya }\end{array}$ & $\begin{array}{l}0.00 \\
0\end{array}$ & $\begin{array}{l}0.00 \\
0\end{array}$ & $\begin{array}{l}0.70 \\
7\end{array}$ & $\begin{array}{l}0.00 \\
0\end{array}$ & $\begin{array}{l}0.00 \\
0\end{array}$ & $\begin{array}{l}0.71 \\
0\end{array}$ & $\begin{array}{r}3.04 \\
9\end{array}$ & $\begin{array}{r}1.27 \\
7\end{array}$ & $\begin{array}{r}0.29 \\
5\end{array}$ & $\begin{array}{l}10 \\
6\end{array}$ \\
\hline $\begin{array}{l}\text { Akademi } \\
\text { Teknik } \\
\text { Radiodiag } \\
\text { nostik } \\
\text { Dan } \\
\text { Radiotera } \\
\text { pi } \\
\text { (ATRO) } \\
\text { Banda } \\
\text { Aceh }\end{array}$ & $\begin{array}{l}0.03 \\
8\end{array}$ & $\begin{array}{l}0.01 \\
8\end{array}$ & $\begin{array}{l}0.01 \\
5\end{array}$ & $\begin{array}{l}0.03 \\
8\end{array}$ & $\begin{array}{l}0.04 \\
2\end{array}$ & $\begin{array}{l}0.01 \\
5\end{array}$ & $\begin{array}{r}2.81 \\
7\end{array}$ & $\begin{array}{r}2.21 \\
1\end{array}$ & $\begin{array}{r}0.44 \\
0\end{array}$ & 52 \\
\hline $\begin{array}{l}\text { Akademi } \\
\text { Fisioterap } \\
\text { i } \\
\text { Muhamm } \\
\text { adiyah } \\
\text { Aceh }\end{array}$ & $\begin{array}{l}0.00 \\
0\end{array}$ & $\begin{array}{l}0.00 \\
6\end{array}$ & $\begin{array}{l}0.70 \\
7\end{array}$ & $\begin{array}{l}0.00 \\
0\end{array}$ & $\begin{array}{l}0.00 \\
8\end{array}$ & $\begin{array}{l}0.71 \\
0\end{array}$ & $\begin{array}{r}3.04 \\
3\end{array}$ & $\begin{array}{r}1.27 \\
7\end{array}$ & $\begin{array}{r}0.29 \\
6\end{array}$ & $\begin{array}{l}10 \\
5\end{array}$ \\
\hline $\begin{array}{l}\text { Akademi } \\
\text { Keperawa } \\
\text { tan } \\
\text { Muhamm } \\
\text { adiyah } \\
\text { Bireuen }\end{array}$ & $\begin{array}{l}0.02 \\
4\end{array}$ & $\begin{array}{l}0.02 \\
1\end{array}$ & $\begin{array}{l}0.01 \\
7\end{array}$ & $\begin{array}{l}0.02 \\
4\end{array}$ & $\begin{array}{l}0.00 \\
0\end{array}$ & $\begin{array}{l}0.71 \\
0\end{array}$ & $\begin{array}{r}2.93 \\
8\end{array}$ & $\begin{array}{r}1.93 \\
7\end{array}$ & $\begin{array}{r}0.39 \\
7\end{array}$ & 82 \\
\hline $\begin{array}{l}\text { Akademi } \\
\text { Manajeme } \\
\text { n Gunung } \\
\text { Leuser }\end{array}$ & $\begin{array}{l}0.00 \\
0\end{array}$ & $\begin{array}{l}0.00 \\
0\end{array}$ & $\begin{array}{l}0.70 \\
7\end{array}$ & $\begin{array}{l}0.00 \\
0\end{array}$ & $\begin{array}{l}0.00 \\
0\end{array}$ & $\begin{array}{l}0.71 \\
0\end{array}$ & $\begin{array}{r}3.04 \\
9\end{array}$ & $\begin{array}{r}1.27 \\
7\end{array}$ & $\begin{array}{r}0.29 \\
5\end{array}$ & $\begin{array}{l}10 \\
6\end{array}$ \\
\hline $\begin{array}{l}\text { Politeknik } \\
\text { Aceh }\end{array}$ & $\begin{array}{l}0.24 \\
9\end{array}$ & $\begin{array}{l}0.05 \\
4\end{array}$ & $\begin{array}{l}0.01 \\
3\end{array}$ & $\begin{array}{l}0.24 \\
9\end{array}$ & $\begin{array}{l}0.10 \\
1\end{array}$ & $\begin{array}{l}0.01 \\
3\end{array}$ & $\begin{array}{r}2.55 \\
8\end{array}$ & $\begin{array}{r}2.24 \\
3\end{array}$ & $\begin{array}{r}0.46 \\
7\end{array}$ & 13 \\
\hline $\begin{array}{l}\text { Politeknik } \\
\text { Indonesia } \\
\text { Venezuela }\end{array}$ & $\begin{array}{l}0.13 \\
6\end{array}$ & $\begin{array}{l}0.05 \\
8\end{array}$ & $\begin{array}{l}0.01 \\
4\end{array}$ & $\begin{array}{l}0.13 \\
6\end{array}$ & $\begin{array}{l}0.10 \\
0\end{array}$ & $\begin{array}{l}0.01 \\
4\end{array}$ & $\begin{array}{r}2.66 \\
7\end{array}$ & $\begin{array}{r}2.22 \\
2\end{array}$ & $\begin{array}{r}0.45 \\
5\end{array}$ & 23 \\
\hline $\begin{array}{l}\text { Politeknik } \\
\text { Aceh } \\
\text { Selatan }\end{array}$ & $\begin{array}{l}0.16 \\
9\end{array}$ & $\begin{array}{l}0.05 \\
9\end{array}$ & $\begin{array}{l}0.01 \\
4\end{array}$ & $\begin{array}{l}0.16 \\
9\end{array}$ & $\begin{array}{l}0.20 \\
6\end{array}$ & $\begin{array}{l}0.01 \\
5\end{array}$ & $\begin{array}{r}2.57 \\
3\end{array}$ & $\begin{array}{r}2.23 \\
4\end{array}$ & $\begin{array}{r}0.46 \\
5\end{array}$ & 14 \\
\hline $\begin{array}{l}\text { Politeknik } \\
\text { Kutaraja }\end{array}$ & $\begin{array}{l}0.00 \\
0\end{array}$ & $\begin{array}{l}0.00 \\
0\end{array}$ & $\begin{array}{l}0.70 \\
7\end{array}$ & $\begin{array}{l}0.00 \\
0\end{array}$ & $\begin{array}{l}0.00 \\
0\end{array}$ & $\begin{array}{l}0.71 \\
0\end{array}$ & $\begin{array}{r}3.04 \\
9\end{array}$ & $\begin{array}{r}1.27 \\
7\end{array}$ & $\begin{array}{r}0.29 \\
5\end{array}$ & $\begin{array}{l}10 \\
6\end{array}$ \\
\hline $\mathrm{A}+$ & $\begin{array}{r}1.46 \\
7\end{array}$ & $\begin{array}{r}1.13 \\
2\end{array}$ & $\begin{array}{r}0.01 \\
2\end{array}$ & $\begin{array}{r}1.46 \\
7\end{array}$ & $\begin{array}{r}1.65 \\
5\end{array}$ & $\begin{array}{r}0.01 \\
2\end{array}$ & & & & \\
\hline A- & $\begin{array}{r}0.00 \\
0\end{array}$ & $\begin{array}{r}0.00 \\
0\end{array}$ & $\begin{array}{r}1.89 \\
8\end{array}$ & $\begin{array}{r}0.00 \\
0\end{array}$ & $\begin{array}{r}0.00 \\
0\end{array}$ & $\begin{array}{r}1.17 \\
1\end{array}$ & & & & \\
\hline
\end{tabular}

Penelitian tentang pengambilan keputusan ini mengimplementasikan metode TOPSIS. Proses dari perhitungannya sendiri melalui tahapan-tahapan dilakukan untuk memilih Perguruan Tinggi yang paling direkomendasikan dengan mengurutkan dari hasil perhitungannya.

Perhitungan TOPSIS diawali dengan membentuk matriks keputusan yang kemudian dinormalisasi, dilanjutkan dengan pembobotan matriks keputusan ternormalisasi. Langkah tersebut dilakukan untuk menentukan matriks solusi ideal positif dan solusi ideal negatif. Tahapan terakhir dari metode ini yaitu menghitung nilai preferensi dari masing-masing alternatif (Vi) guna mendapatkan hasil akhir, nilai Vi yang paling tinggi menunjukkan alternatif terbaik yang terpilih.

Berdasarkan dengan hasil akhir maka Perguruan Tinggi Swasta (PTS) Wilayah Kopertis XIII Aceh yang terbaik dengan posisi 25 terbaik adalah:

1. Universitas Al Muslim

2. Universitas Muhammadiyah Aceh

3. Universitas Serambi Mekkah

4. Universitas Jabal Ghafur

5. Universitas Abulyatama

6. STKIP Bina Bangsa Getsempena

7. Universitas Ubudiyah Indonesia

8. Universitas Iskandar Muda

9. Sekolah Tinggi Ilmu Ekonomi Sabang

10. Universitas Sains Cut Nyak Dhien

11. STKIP Bina Bangsa Meulaboh

12. STIKES Nurul Hasanah Kutacane

13. STIKES Nurul Hasanah Kutacane

14. Politeknik Aceh Selatan

15. STKIP Muhammadiyah Aceh Barat Daya

16. STIE Bumi Persada Lhokseumawe

17. STIKES Getsempena Lhoksukon

18. STIKES Darussalam Lhokseumawe

19. STIKES Muhammadiyah Lhokseumawe

20. STIKES Cut Nyak Dhien Langsa

21. Akademi Keuangan Perbankan Nusantara

22. Sekolah Tinggi Ilmu Administrasi Pelita Nusantara

23. Politeknik Indonesia Venezuela

24. AMIK Indonesia

25. Sekolah Tinggi Ilmu Pertanian Yashafa 


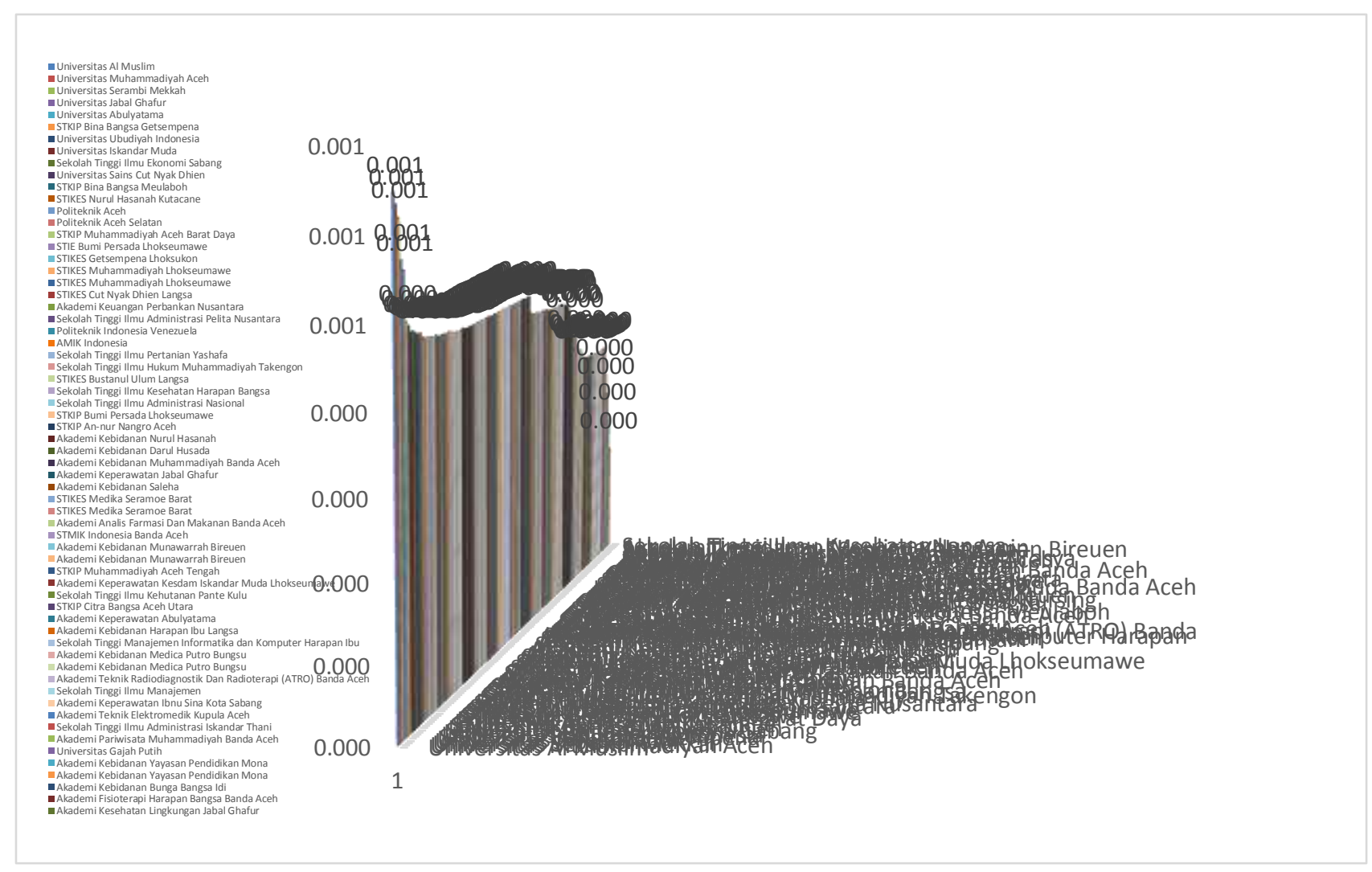

Gambar 2. Hasil TOPSIS dalam bentuk Grafik

\section{Kesimpulan dan Saran}

Penggunaan metode TOPSIS dapat digunakan untuk memecahkan masalah penyeleksian Perguruan Tinggi, hasil perhitungan menunjukkan bahwa kriteria yang paling diprioritaskan adalah kriteria rasio dosen dibandingkan dengan kriteria lainnya seperti jumlah dosen tetap, jumlah mahasiswa, dan rasio dosen mahasiswa.

Saran yang diberikan untuk pengembangan penelitian selanjutnya adalah metode TOPSIS bukanlah satusatunya metode pengambilan keputusan yang digunakan, dalam memecahkan masalah multikriteria akan lebih baik jika dicoba penggabungan metode lain supaya hasil yag didapat lebih efektif dan lebih baik. Selain itu, penelitian selanjutnya juga mengukur dari jumlah prodi setiap masing-masing Perguruan Tinggi, jumlah dosen yang memiliki fungsional dari jumlah tetap pada Program Studi, Jumlah Dosen Tetap dengan Kualifikasi Pendidikan Magister, serta pembobotan dari setiap penilaian kepangkatan hingga jabatan fungsional setiap dosen masing-masing Perguruan Tinggi agar informasi menjadi bermanfaat.

\section{Daftar Pustaka}

Ahmad, L., 2016. Pengaruh Pemberdayaan dan Dukungan Organisasi Terhadap Motivasi Kerja Pegawai Kantor Camat di Kota Banda Aceh. Jemensri (Jurnal Ekonomi Manajemen dan Sekretari), 1(1), pp.42-54.

Boran, F.E., Genç, S., Kurt, M. and Akay, D., 2009. A multi-criteria intuitionistic fuzzy group decision making for supplier selection with TOPSIS method. Expert Systems with Applications, 36(8), pp.1136311368.

Chamid, A.A. and Murti, A.C., 2017. Kombinasi Metode Ahp dan Topsis pada Sistem Pendukung Keputusan. Prosiding SNATIF, pp.115-119.

Faza, A.P. and Supriyanto, C., 2016. Implementasi Metode Ahp-Topsis Untuk Menentukan Kelayakan Pinjaman Modal (Studi Kasus Pada Koperasi Simpan Pinjam Jasa Pekalongan). 
Gustriansyah, R., 2016. Sistem Pendukung Keputusan Pemilihan Dosen Berprestasi Dengan Metode ANP dan TOPSIS.

Ihsanuddin, I., 2014. Kompleksitas Tugas Kerja dan Kepuasan Kerja Pegawai. Jurnal Ekonomi Manajemen dan Bisnis (EMBis), 2(2), pp.356-366.

Irma, Irma, Khairul Amri, and Munawir Munawir. "Persepsi Mahasiswa Terhadap Kualitas Layanan Pendidikan Akademi Manajemen Informatika dan Komputer Indonesia (AMIKI) Banda Aceh." Jurnal Ekonomi Manajemen dan Bisnis (EMBis) 1, no. 1 (2013): 118-139.

Joni, I.D.M.A.B. and Ariana, A.A.G.B., 2016. Sistem Pendukung Keputusan Seleksi Penerimaan Dosen Tetap Yayasan Dengan Metode Fuzzy-AHP. Network Engineering Research Operation [NERO], $1(2)$.

Munawir, M. and Ardiansyah, A., 2017. Decision Support System Pemilihan Karyawan Berprestasi Dengan Pendekatan Analisa Gap Profile matching di Kantor Perwakilan Bank Indonesia Provinsi Aceh. Jurnal JTIK (Jurnal Teknologi Informasi dan Komunikasi), 1(1), pp.7-14.

Nasir, N. and Muhammad, S., 2017, October. Dampak Industri Kreatif Dan Strategi Terhadap Peningkatan Kesejahteraan Masyarakat Di Kabupaten Aceh Besar (Studi Pada Subsektor Industri Kerajinan Di Kabupaten Aceh Besar. In Prosiding Seminar Nasional USM (Vol. 1, No. 1).

Prasetyanti, D.N. and Listyaningrum, R., 2017. Kaji Banding Metode Topsis, Saw Dan Ahp-Topsis Guna Menentukan Ukt Mahasiswa Baru Di Politeknik Negeri Cilacap. Jurnal Infotekmesin, 8(1).

Rizal, S., 2017. Pengaruh Kecerdasan Emosional, Perilaku Koqnitif, Kemampuan Personal dan Kompetensi Kepemimpinan Terhadap Kinerja Koperasi di Provinsi Aceh. Jurnal EMT KITA, 1(1), pp.36-49.

Rifai, A. and Arsalan, O., 2017. Perancangan Sistem Informasi Kinerja Dosen Menggunakan Metode Topsis. KNTIA, 4.
Sarboini, S., Surya, J. and Safiansyah, W., 2017. Pengaruh Kepemimpinan dan Team Work Terhadap Kinerja Pegawai Pada PT. PLN (PERSERO) Cabang Banda Aceh. Jurnal EMT KITA, 1(2), pp.86-90.

Yuliana, A. and Pratomo, D.B., 2017, February. Algoritma Decision Tree (C4. 5) untuk Memprediksi Kepuasan Mahasiswa Terhadap Kinerja Dosen Politeknik TEDC Bandung. In Seminar Nasional Inovasi Teknologi (Vol. 1, No. 1, pp. 365-372). 